\title{
Article \\ Architectural Significance of the Seokguram Buddhist Grotto in Gyeongju (Korea)
}

\author{
Francisco Salguero-Andújar ${ }^{1,+} \mathbb{D}$, Fulgencio Prat-Hurtado ${ }^{1,+}$, Inmaculada Rodriguez-Cunill ${ }^{2,+} \mathbb{D}$ \\ and Joseph Cabeza-Lainez ${ }^{3, *,+}$ (D) \\ 1 School of Engineering, Campus de El Carmen, University of Huelva, 21007 Huelva, Spain; \\ salguero@uhu.es (F.S.-A.); prat@uhu.es (F.P.-H.) \\ 2 Faculty of Fine Arts, Department of Painting, University of Sevilla, 41003 Sevilla, Spain; cunill@us.es \\ 3 School of Architecture, Department of Composition, University of Sevilla, 41012 Sevilla, Spain \\ * Correspondence: crowley@us.es \\ $\dagger$ The four authors contributed equally to this research.
}

Citation: Salguero-Andújar, F.; Prat-Hurtado, F.; Rodriguez-Cunill, I.; Cabeza-Lainez, J. Architectural Significance of the Seokguram Buddhist Grotto in Gyeongju (Korea). Buildings 2022, 12, 3. https:// doi.org/10.3390/buildings12010003

Academic Editors: Paula Lopez-Arce and Ainara Zornoza-Indart

Received: 11 November 2021

Accepted: 19 December 2021

Published: 21 December 2021

Publisher's Note: MDPI stays neutral with regard to jurisdictional claims in published maps and institutional affiliations.

Copyright: (C) 2021 by the authors. Licensee MDPI, Basel, Switzerland. This article is an open access article distributed under the terms and conditions of the Creative Commons Attribution (CC BY) license (https:// creativecommons.org/licenses/by/ $4.0 /)$.

\begin{abstract}
The purpose of this article is to disclose the hidden architectural proportions and true nature of the Korean national treasure in Seokguram Grotto, Gyeongju. The authors compare its features with those of other ancient hypogeal or ashlar constructions with the intention of rediscovering its relevant configuration and latent structural properties in order to demonstrate its uniqueness. The methods employed in the research belong initially to architectural design and composition to advance in the later stages to the nuances of stone masonry, lighting effects and especially cohesive construction. In this discussion and thorough analysis diverse philosophical and scientific subtleties are brought to the surface. The results demonstrate significant potential thanks to recent architectural developments, such as Tadao Ando's Buddha Hill in Hokkaido (2017) and the authors' own proposal for a Buddhist monument.
\end{abstract}

Keywords: korean heritage; asian architecture; tadao ando; hypogeal chambers; architectural proportions; ashlar construction; innovative architectural projects based on tradition

\section{Introduction to the Seokguram Fascination}

For centuries, the Buddha secluded in the hill of Seokguram has been a source of attraction for the Korean people and foreign travelers. It would appear that there are no appropriate words to describe one's feelings about this temple, no matter what language you speak. Indeed, in the book of Joon- Sik Choi [1] we read:

The moment you see it you will be stunned by the breathtaking sight. It radiates a dignified yet compassionate aura. The cave in which the Buddha statue is enshrined does not feel like being from this world. It is a wondrous sight that cannot be properly expressed in words. You cannot help but wonder how on earth it was possible to carve such a soft and flowing appearance out of granite, a rock that is so hard that it is considered the most difficult stone to sculpt. Various thoughts will come to mind, but I think it is best to just observe without trying to think. Isn't it enough for the best works of art simply to exist?

In the same way, the celebrated work of Yu Hong-June [2] cites the manuscript of Ko Yusoep's "Our Art and Handicrafts":

This great statue, beginning as a bloodless, passionless lump of granite, has been endowed with a strong pulse, breath, divinity, gentleness and dignity. When unveiled, the joy was surely not limited to the sculptor, but extended throughout Silla and echoed towards the cosmos. 
Even today, most people who visit the Seokguram feel as if they lacked the vocabulary to express what they have witnessed in it. Some have compared this situation to experience of contemplating for the first time the sculpture of the Pietà by Michelangelo Buonarroti (unfortunately also through a glass pane), today located to the right side of the entrance of the Basilica of St. Peter in Rome.

However, history of art comes to our aid when we intend to find words to express what we may recollect in such quaint occasions. The feeling stems from the 19th-century French author Stendhal (pseudonym of Marie-Henri Beyle), who described his own impressions during a stint in Florence in 1817 in his book Naples and Florence: A Journey from Milan to Reggio.

When he visited the Basilica of Santa Croce, where Niccolò Machiavelli, Michelangelo Buonarroti and Galileo Galilei are interred, he saw Giotto's frescoes for the first time and was overwhelmed with emotion. He wrote:

I was in a sort of ecstasy, from the idea of being in Florence, close to the great men whose tombs I had seen. Absorbed in the contemplation of sublime beauty ... I reached the point where one encounters celestial sensations ... Everything spoke so vividly to my soul [3].

The ecstatic experience was only named in 1979, as it was described by the Italian psychiatrist Graziella Magherini, who reported more than 100 similar cases among tourists and visitors in Florence. There is no scientific proof to define the so-called Stendhal syndrome as a specific psychiatric disorder; however, there is evidence that the same cerebral areas involved in emotional reactions are activated during exposure to artworks. Thus, Salguero and Cabeza-Lainez [4] propose to coin the term "Seokguram Syndrome" to describe what happens internally when we contemplate this Korean masterpiece of universal art.

The authors believe that there are not merely psycho-physic motives but also scientific reasons behind the diverse sensations induced when contemplating this monument. The Seokguram enclave connects with a cherished Buddhist tradition of hypogeal compounds [5,6] that goes back thousands of years and originated mainly in India [7]. The climate of the Indian plateau and the geologic characteristics of its soil favored the introduction of this particular system of constructions [8] for religious communities and monasteries alike.

Besides, the whole monastery, as a closed resort, evokes a cosmic order that is manifest through its refined character and proportions, aspects that in many senses served as a model in other eastern territories [9], especially in Japan and China [10,11].

The seemingly nondescript artificial cave inaugurated a novel concept of space [12] for Asia that was subsequently forsaken for centuries and may hopefully be experiencing a contemporary revival. Consequently, in the ensuing sections, we disclose the main features of Seokguram.

\section{Materials and Methods}

As a matter of principle, we would like discuss the main features of the tectonic art in the ancient kingdoms. There are specific aspects of the architecture of the Unified Silla Period in Korea (668-935 A.D.), to which the Seokguram enclave belongs, that are designated as exclusive to its epoch and culture. One of them is the specific stone carving method known as 'grangie', which consists of adapting the straight contours of rectangular blocks to dovetail within the natural stones located underneath in a manner of foundation (Figure 1). 


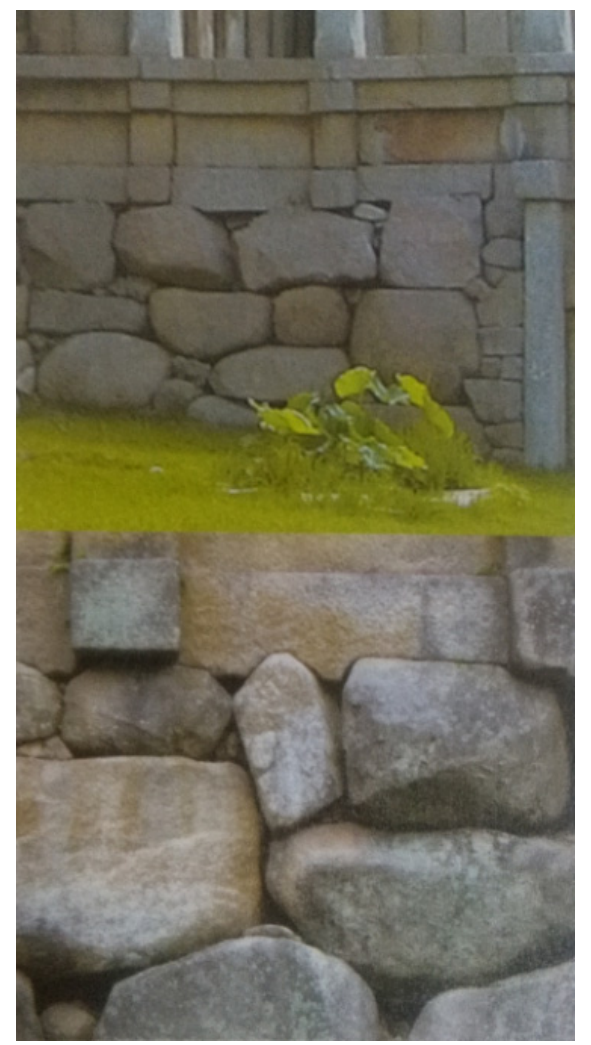

Figure 1. The ‘Grangie' ('Kǔraeng'i') technique. Source.

In wooden architecture, this is known as the 'kǔraeng' $i$ ' technique and, according to several authors, it only appears in Korea. However, we have found some examples of this 'technique' in other places and epochs, such as Machu Picchu (literally 'Old Mountain') in Peru, built between 1438 and 1470 A.D. (Figure 2), and at a stone wall of the church of Santa María de Melque, which dates from the 10th century in Toledo (Spain), to name just a few examples (Figure 3).

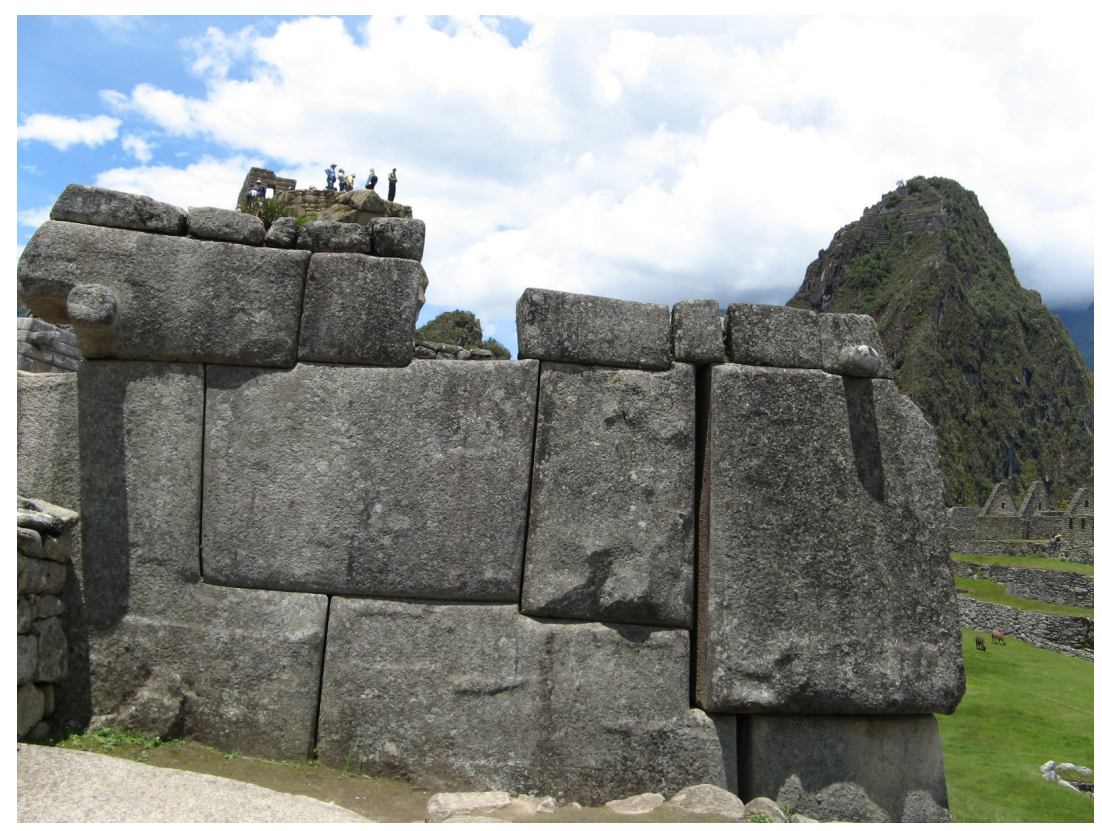

Figure 2. Cyclopean wall in Machu Picchu (Peru). 


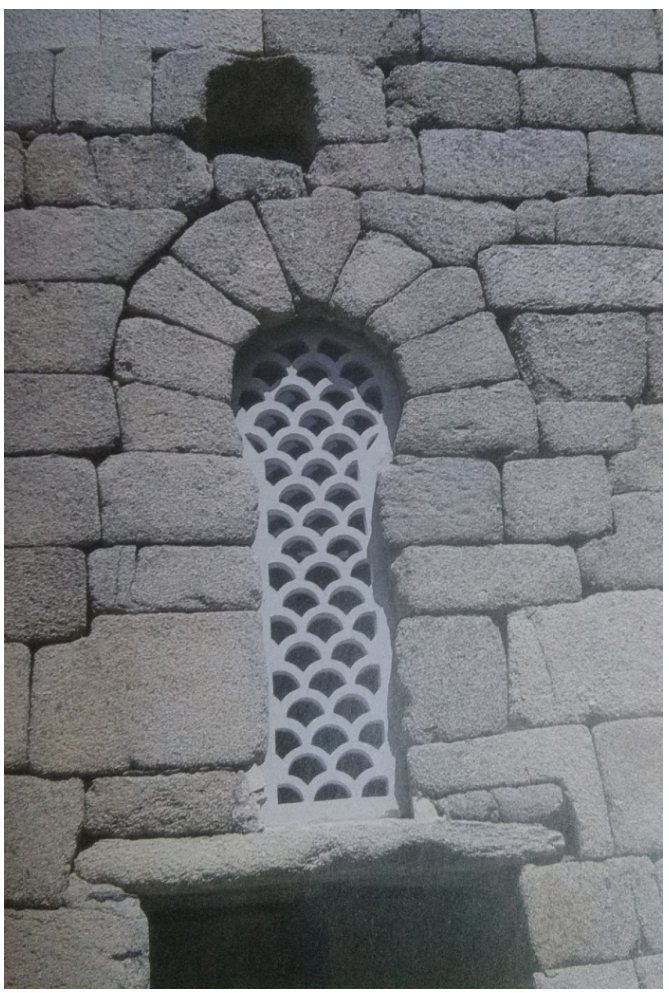

Figure 3. Window of the church of Santa María de Melque 10th century, Toledo (Spain).

Another typical feature of the original Seokguram temple is the placement of granite ashlars without mortar [4]. In Spain, the most significant construction built using this technique is the Roman aqueduct of Segovia (Figure 4).

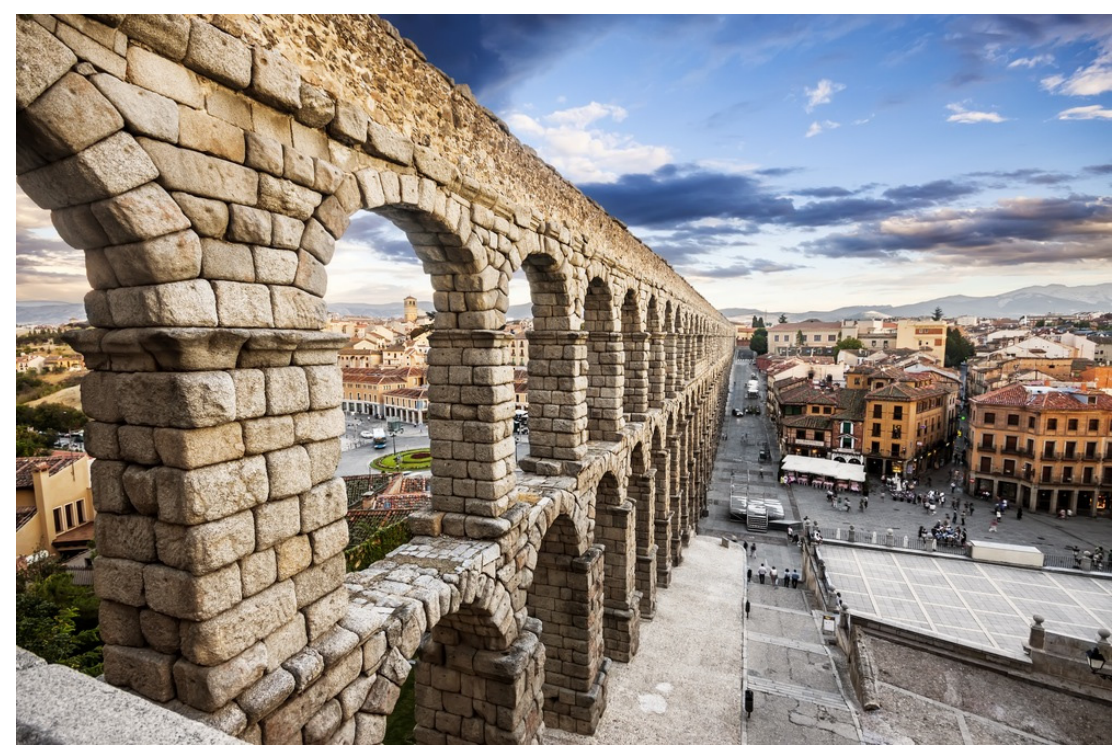

Figure 4. Aqueduct of Segovia (Spain). Granite ashlars without mortar.

It is necessary to outline a recent phenomenon by which the vibrations due to traffic and musical concerts in its vicinity are literally pulverizing the granite ashlars of this construction. These circumstance should also be taken into account in the conservation of the Seokguram temple through precise measurements of the vibrations to which it is subject daily. 


\subsection{The Dome of the Seokguram Temple Compared to Similar Mounds}

Being a singular case in universal architecture, it is difficult to find examples of real domes built using ashlars directly cut from the rock. One of the most cited examples is the Treasury of Atreus or Tomb of Agamemnon. It is a large "tholos" tomb on the Panagitsa Hill at Mycenae, Greece, which was constructed during the Bronze Age (around 1250 B.C.). The lintel stone above the doorway weighs 120 tons and, with approximate dimensions of $8.3 \times 5.2 \times 1.2 \mathrm{~m}$, it constitutes the largest of its kind in the world.

However, as Figures 5 and 6 show, the structure is not a true dome, but instead a corbelled or false vault composed by the nominal displacement of the stones to the inside and towards the apex. This kind of "dome" was also favored by distant cultures, such as Mayan, and thus we infer it to be a constant of human civilization [13].

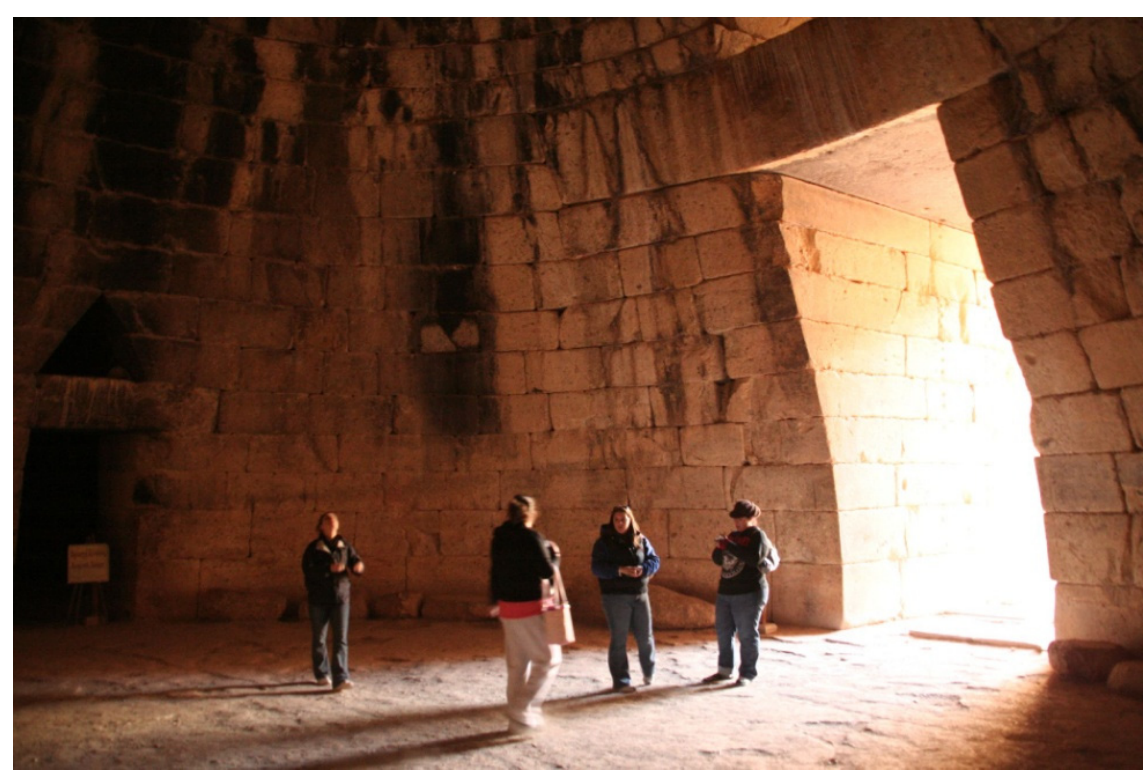

Figure 5. Interior of the Treasury of Atreus, near the entrance.

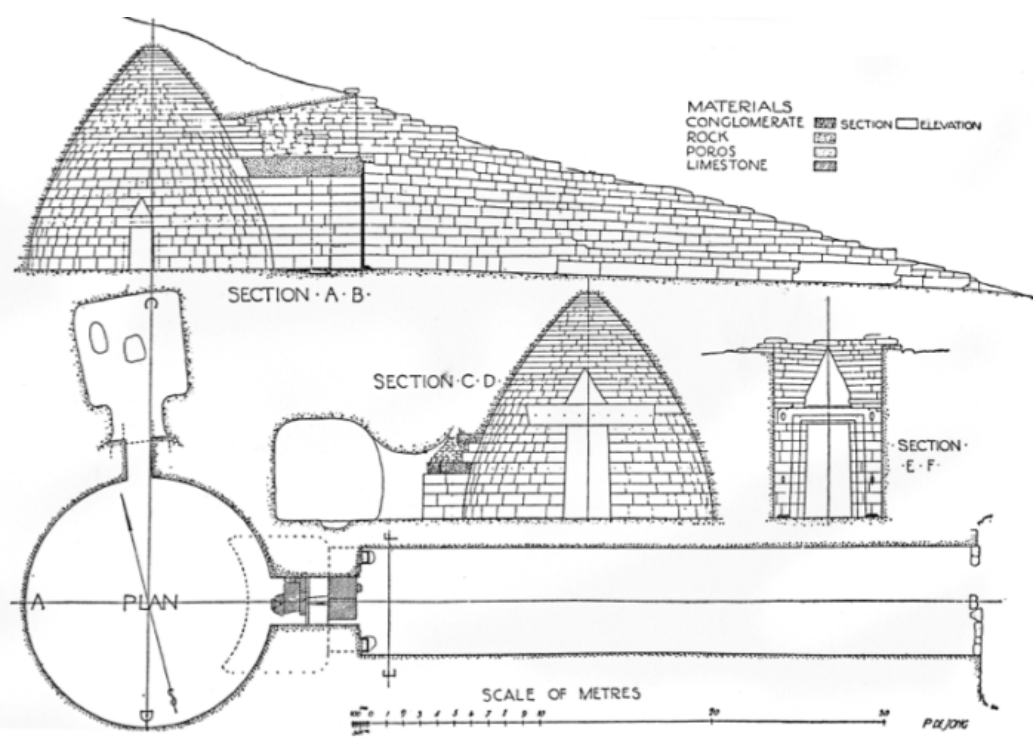

Figure 6. Schematic plan and sections of the Treasure of Atreus.

Another difficulty encountered when locating these types of buildings is that, on a number of occasions, the ceiling of a given structure is no longer extant because it was built with friable materials, and it is therefore very difficult to know if the roofs in question 
were really domes, as is the case of Ggantija, one of the main megalithic complexes of Malta (Figure 7). The two Ggantija structures were erected during the Neolithic period (3600-2500 B.C.), making them more than 5500 years old and thus they constitute the world's second oldest religious structures known to man. The oldest could be the Hal Saflieni hypogeum in Valleta (Malta).

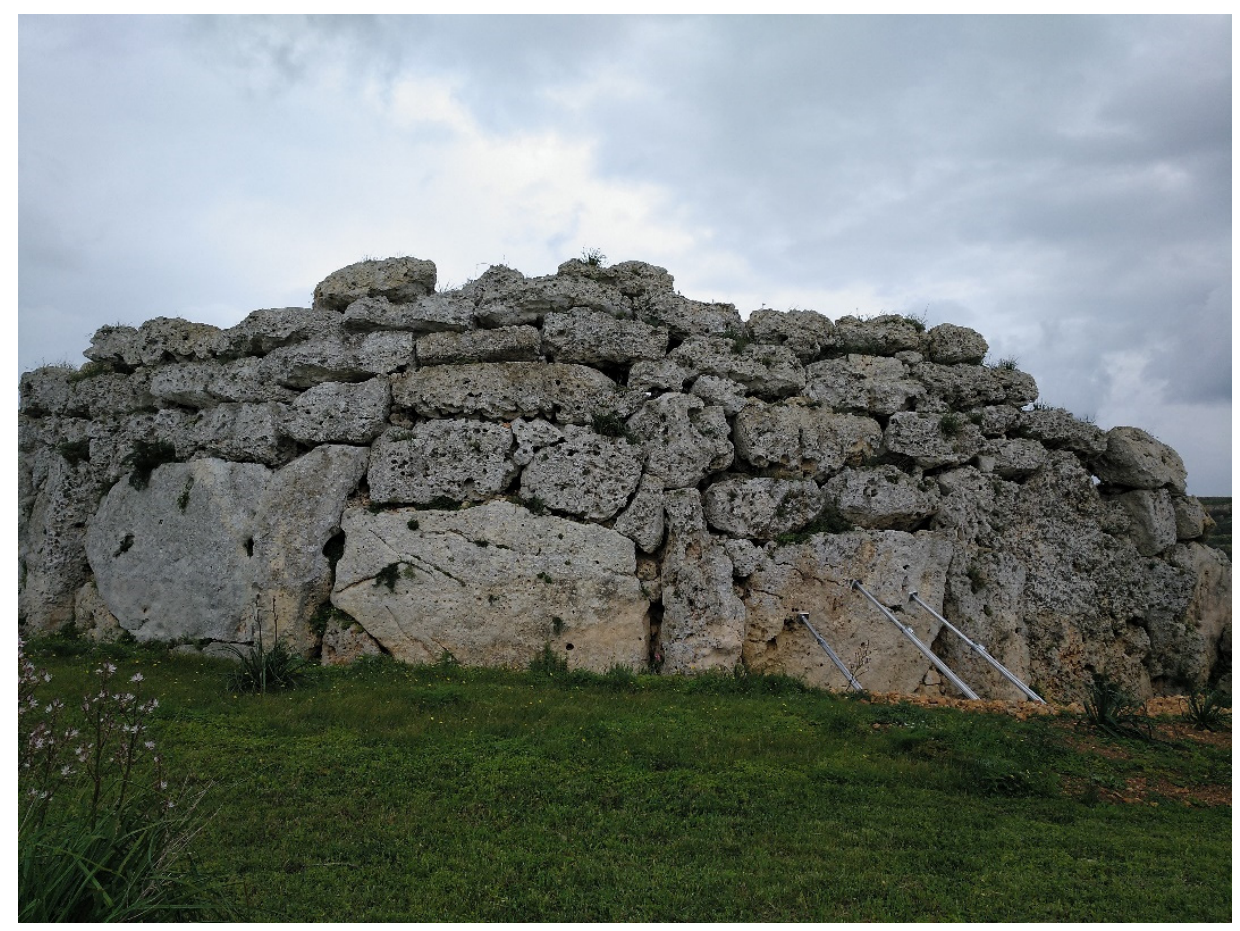

Figure 7. Ggantija, the Megalithic Temples of Malta.

From that moment onwards, tumulus architecture evolved in several cultures around the world, such as those belonging to the Etruscan reigns (Figure 8), the Nuraghic civilization in Sardinia or the Lycian tombs in Antalya (Turkey). Eventually many of the tumuli were transformed hypogeal structures and temples.

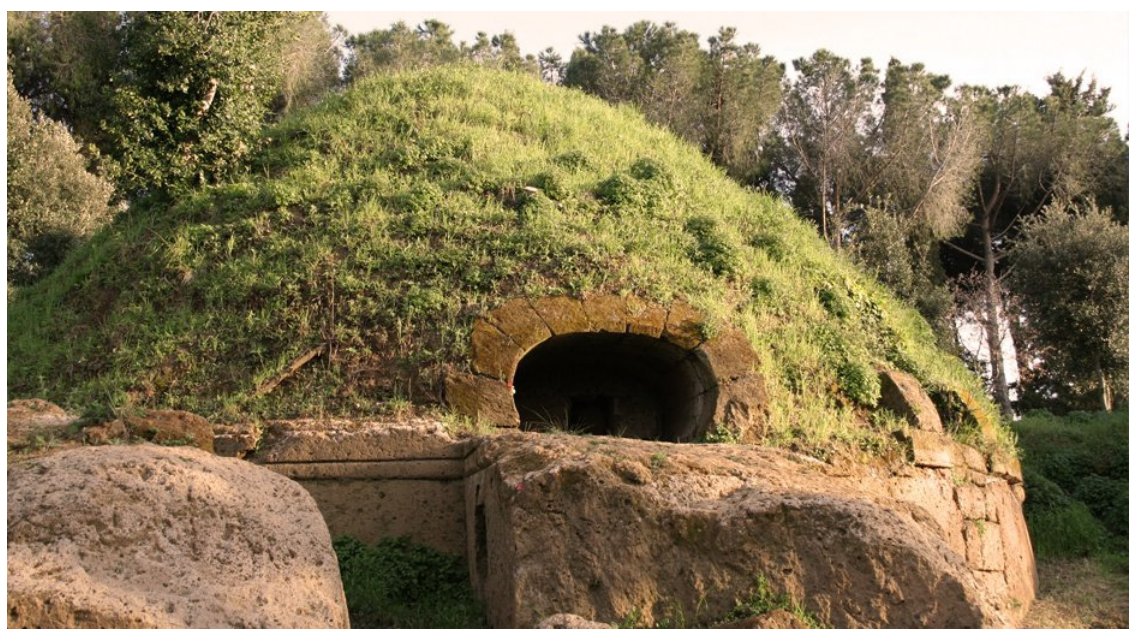

Figure 8. The Etruscan tumuli of Cerveteri. Italy.

One of the problems raised by the construction of domes is that, however light they may be, they tend to create a very strong horizontal thrust force. In Rome, a simple formula was chosen to bear the loads induced by them: placing the support of the dome directly 
over circular or octagonal walls. This is what occurs in the Pantheon of Agrippa (that we will explain later on). In Byzantium [14], a wise equilibrium was devised by setting the walls free of their sustaining role, that is, conceiving the dome over spandrels (Figure 9).

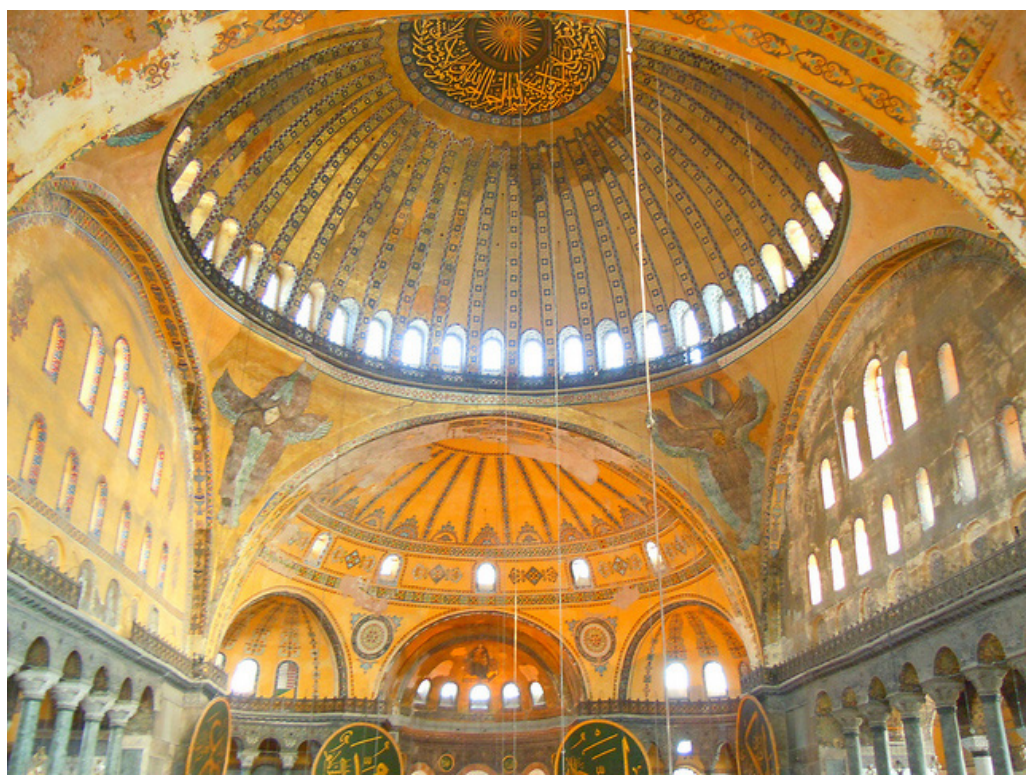

Figure 9. Dome on spandrels at the Hagia Sophia church in Istanbul, Turkey.

In the case of the Roman Pantheon (Figure 10), the dome is supported by means of brickwork discharge arches, ribs made of the same material and hydraulic cement mortar (a kind of roman concrete), but it is not built by the simple stacking of granite blocks as in the case of Seokguram [15].

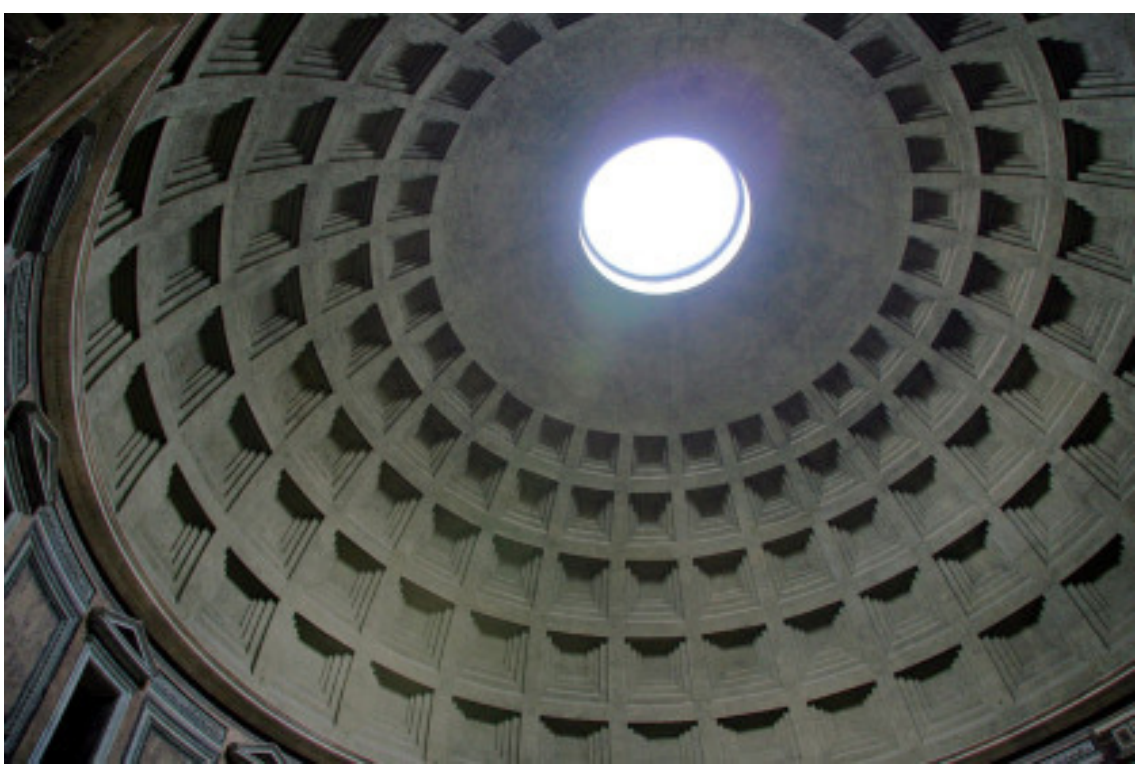

Figure 10. Concentric nerves used for the construction of the Pantheon in Rome.

A rather original formula used to balance the forces induced by the cupola is the one created in 751 A.D. at the Seokguram temple, whereby counterweights or 'forearms' are used, which act as both levers and wedges. As far as we can report, it is the only dome possessing such artifacts among its features (Figure 11). 


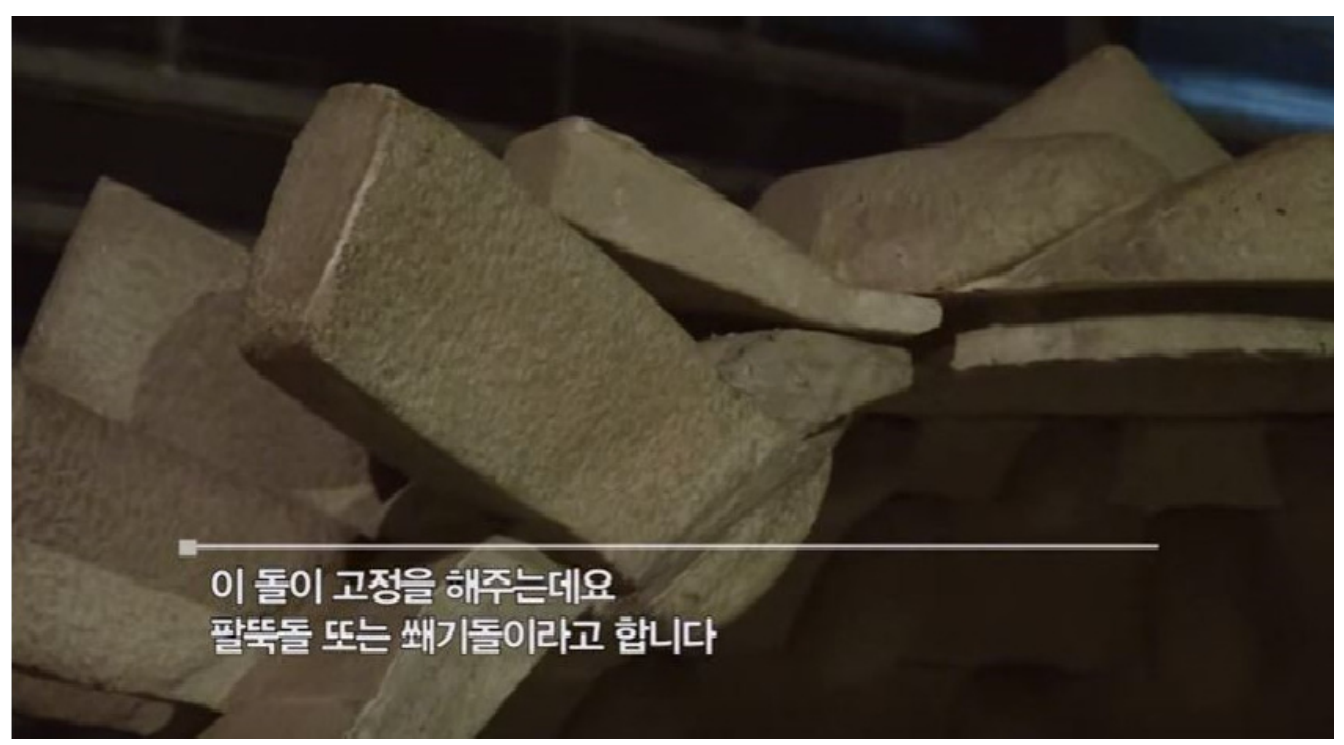

Figure 11. 'Forearms' that balance the horizontal and vertical forces at Seokguram's cupola.

\subsection{Evolution of the Korean Tumuli}

Domes made with masses of stones have been used in Korea since ancient times to mark a kind of ceremonial mound known as a tumulus. It was covered with grass, as we can see in Figure 12. Unlike the Atreus' Treasury these tumuli possessed no internal space, but they encompassed a geomantic significance as ritual landmarks [9]. At a later stage, such landscape's Feng Shui (Pung Sui in Korean) was made apparent by the orderly carving of statues of the twelve celestial branches, also known as the oriental horoscope, which measured the seasons as well as the time. (Figures 13 and 14)

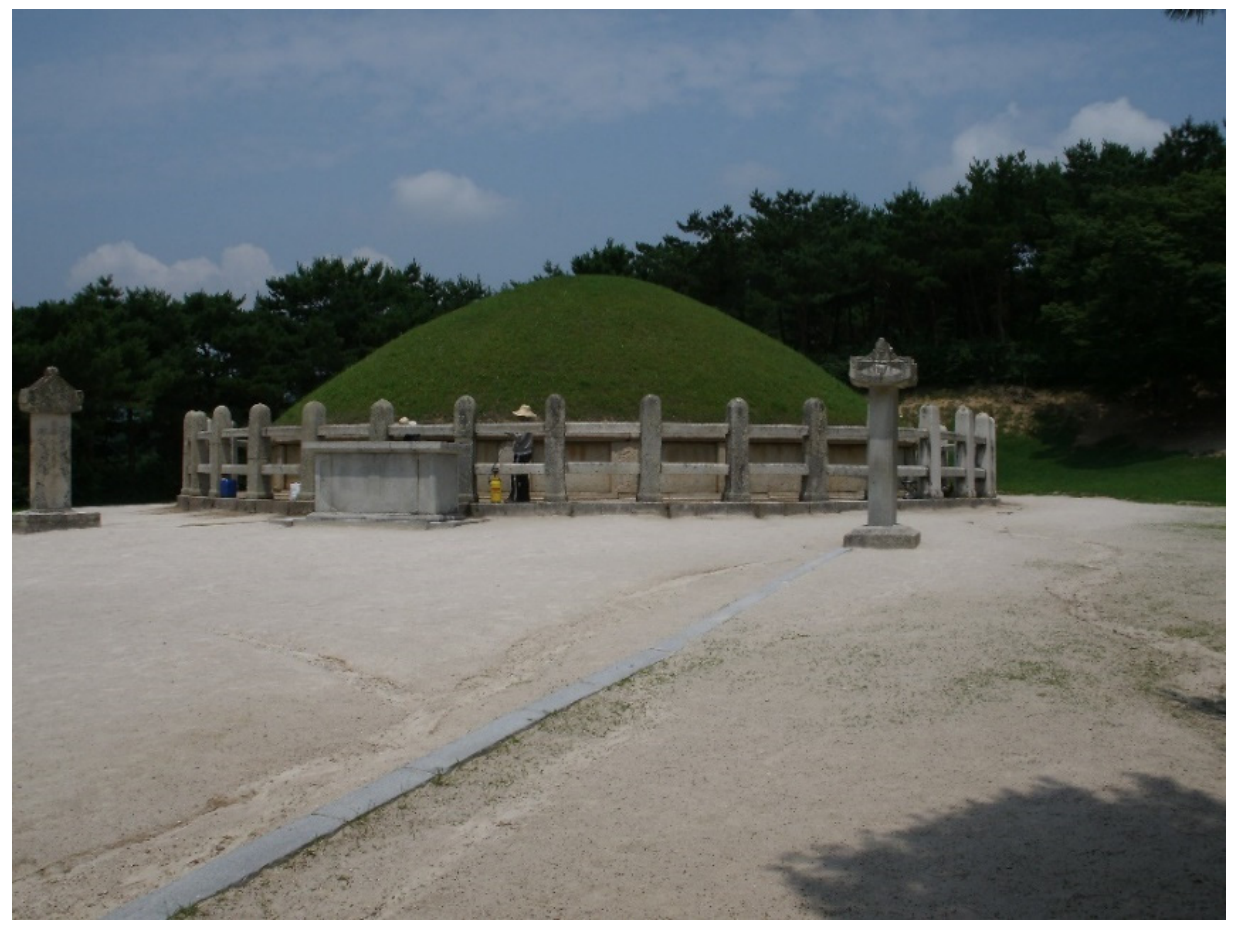

Figure 12. Tumulus of Hwangnam-ri. Gyeongju (Korea). 


$\begin{array}{cc}\text { Ox丑 } & \text { Rat } \\ \text { Hare 卯 } & \text { Tiger 寅 } \\ \text { Serpent } ~ & \text { Dragon 辰 } \\ \text { Ram 未 } & \text { Horse 午 } \\ \text { Bird 酉 } & \text { Ape 申 } \\ \text { Boar 亥 } & \text { Dog 戊 }\end{array}$

Figure 13. The cosmological disposition of the twelve animals found at diverse tumuli in Korea. The hour of the rat is midnight (north), and the hour of the horse is noon (south). The order segues from right to left and top to bottom in each inclined column. The Chinese characters for every branch are given.
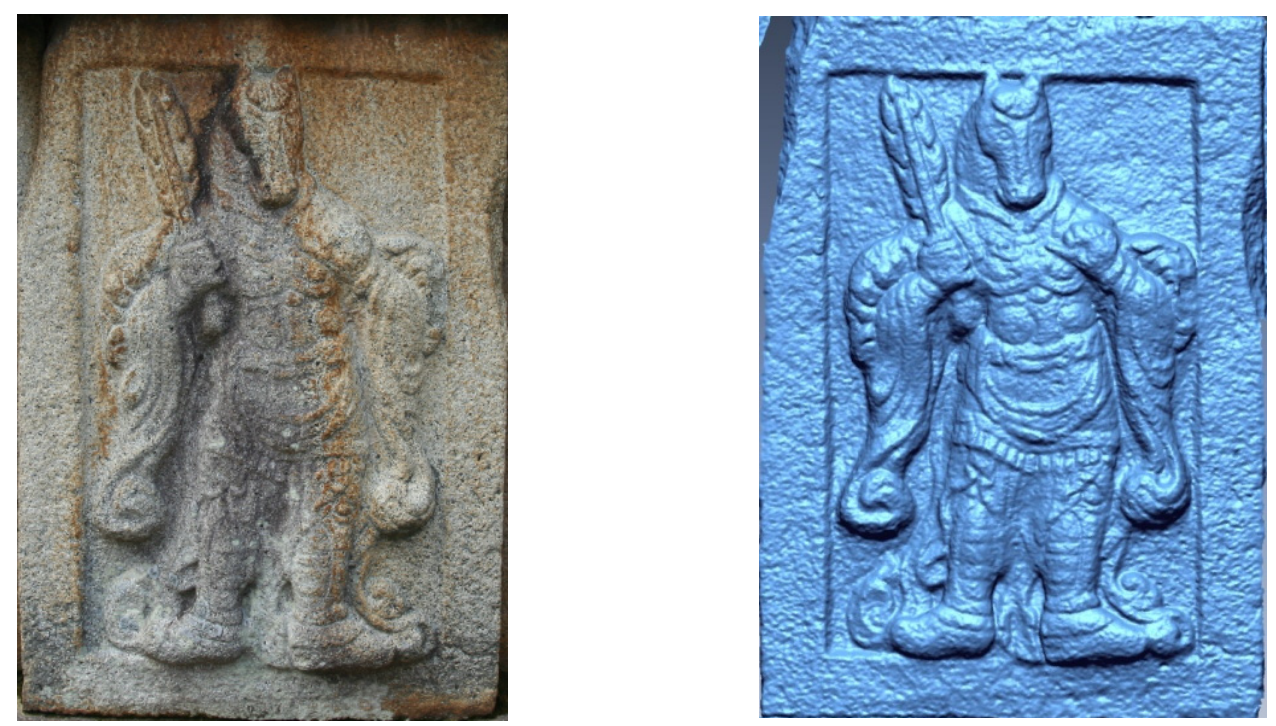

Figure 14. The relief of the horse at a tumulus and its 3D computer reconstruction.

These mythical figures, provided with animal heads, superposed over a human warmongering appearance, were carved in the cylindrical drum of the tumulus at regular intervals with respect to the solar orientation [9], which begins, as we know, with the horse午 (Wu in Chinese). The celestial horse is aligned with due South as it indicates noon (Figure 13). The correct time and sequence order of the figures is as follows: Rat (24 h), Ox $(2 \mathrm{~h})$, Tiger $(4 \mathrm{~h})$, Hare $(6 \mathrm{~h})$, Dragon $(8 \mathrm{~h})$ Serpent $(10 \mathrm{~h})$, Horse $(12 \mathrm{~h})$, Ram $(14 \mathrm{~h})$, Ape (16 h), Bird (18 h), Dog $(20 \mathrm{~h})$ and Boar $(22 \mathrm{~h})$. It is interesting to note that although the animals face their cardinal orientation precisely, the entrance and ceremonial path to the tumulus are usually deviated between 5 and 10 degrees from the astronomical north-south axis for reasons that the authors are still seeking.

In parallel to what happened in India, some centuries before, the tumulus that formed the stupa [6] began to be carved on the inside to become a hypogeal temple devoted to the Buddha, usually known as chaitya. The main reason for such a procedure was a climatic one: the necessity of building a protected space to perform religious ceremonies and liturgy when the blizzards of monsoon weather impeded wandering or any kind of outside practice for both hermits and believers [5]. Such buildings also prevented the incidental killing of any insects that surged in the heat and humidity of the rainy season. In this way, the Seokguram grotto, a renowned Buddhist space, was derived and evolved from the previous ritual tumuli that we have discussed beforehand [7]. 


\section{Results}

\subsection{Mathematic and Geometric Determinations}

After careful analysis, we have obtained some mathematic and cosmic fundamentals of the architecture of Seokguram.

DIN is widely known as the acronym for the Deutsches Institut für Normung (German Institute for Standardization). This institute, based in Berlin, constitutes the national standardization body in Germany. A commonly used DIN standard is DIN 476 (equivalent to ISO 216), which defines paper sizes and has been adopted by most national institutions in the world. It can be assumed that this was developed by the Berliner engineer Dr. Walter Porstmann.

However, we have verified in our research that the universally accepted system of paper sizes might have been invented before the year 751 in the unified Silla kingdom, but a detailed explanation of its scientific value had to wait for the Japanese civil engineer Yoneda Miyoji. In fact, it is in the Seokguram temple (Figures 15 and 16) that we find a demonstration of this and the answer to the origin of the paper size DIN A4, whose greater side is exactly the size of the cha (a unit of measurement used during the Unified Silla Period). Scholars had previously assumed that the cha in use at that time was equivalent to a kokch'ǒk (303 mm), but in his survey of the Pulguksha and Seokpulsha temples, Yoneda discovered that this assumption was incorrect. Surveying each part of the temple's stone stupas, he arrived at measurements equal to 0.98 kokch'ǒk, a unit of measure that he dubbed a tangch'ǒk (Tang foot).

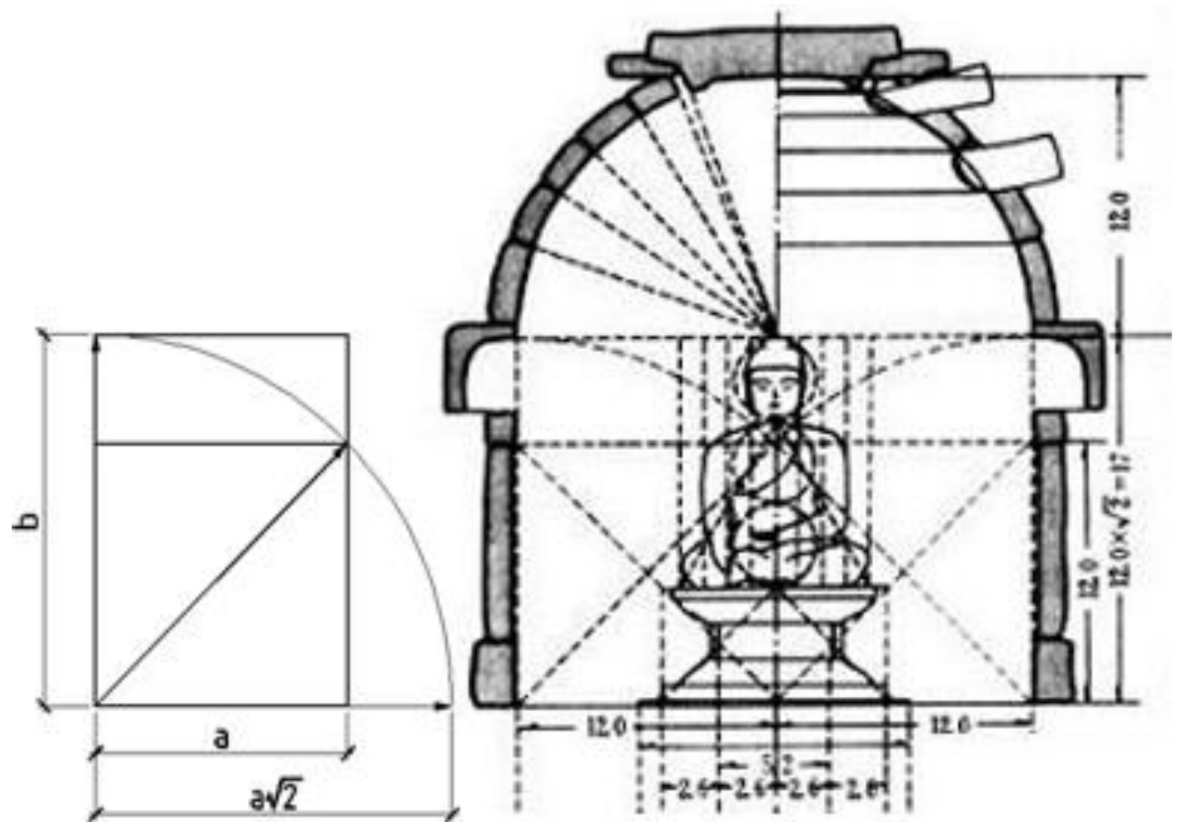

Figure 15. Use of proportions DIN 476 (1922 A.D.) before 751 A.D. by Korean architects and masons.

Indeed, if we establish:

$$
\begin{gathered}
a \cdot b=1 \\
b=a \sqrt{2}
\end{gathered}
$$

We obtain

$$
b=\sqrt{\sqrt{2}}=1.1892
$$

Dividing this amount twice between two, we obtain a tangch'ǒk (Tang foot), i.e.,: $297.3 \mathrm{~mm}$, which is the DIN 476 rounded to $297 \mathrm{~mm}$.

Yoneda's investigation showed that the grotto's rotunda has a radius of 12 cha. If a hexagon were inserted into the circular chamber, the entranceway, also 12 cha in length, would have a width equivalent to one side of the hexagon. The Buddha statue actually stands slightly back from the center of the chamber. If one imagines the entranceway, 12 cha 
across, as if it were one side of an equilateral triangle, the front of the Buddha pedestal would touch the tip of the triangle (Figure 16).

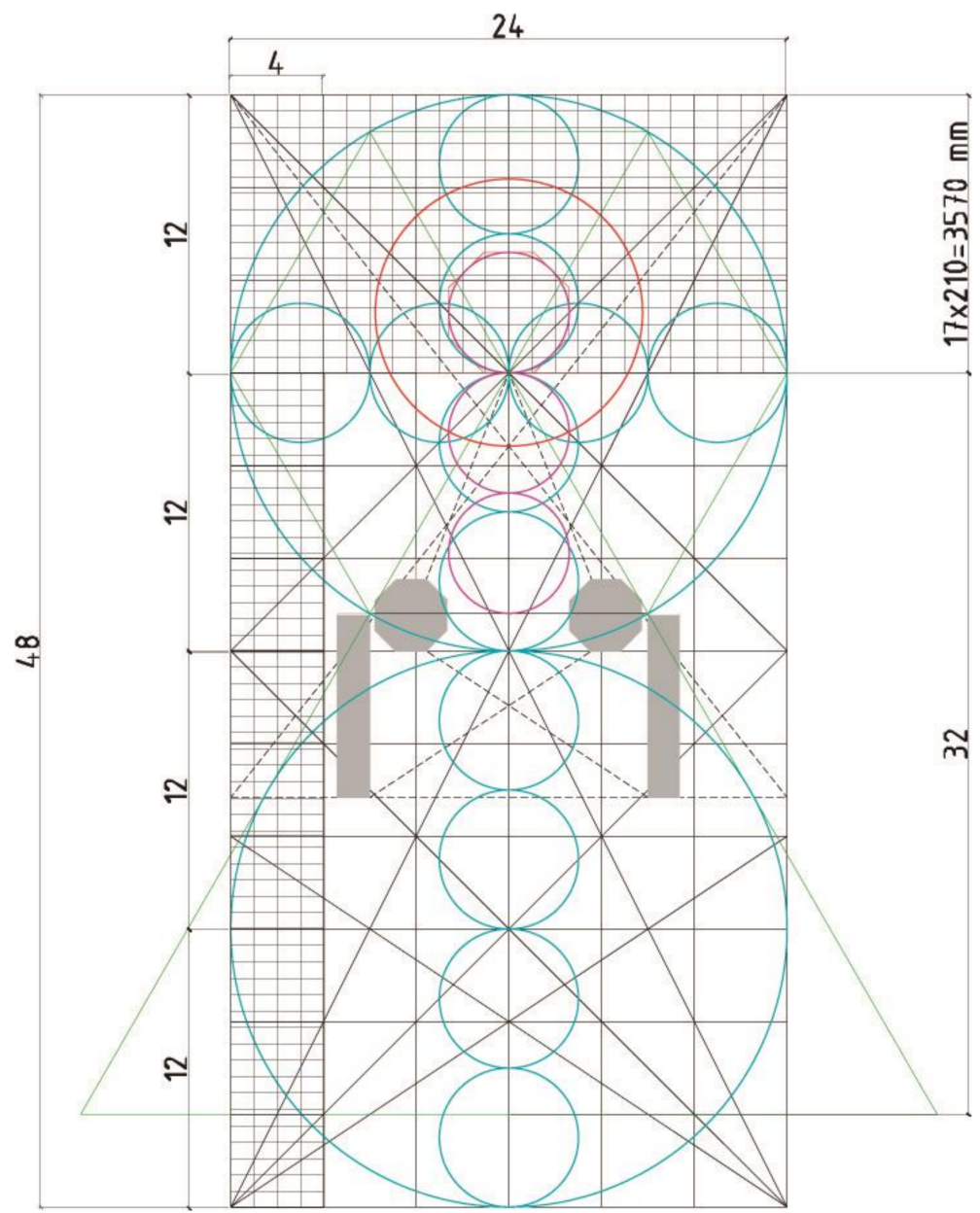

Figure 16. The unusual proportions of the Seokguram temple. Its floor plan can be exactly tessellated with 1632 DIN A4 units.

As it is shown in Figure 16, the Seokguram temple's surface in plan can be tiled exactly with 1632 DIN A4 units, i.e.,: $2^{5} \times 3 \times 17=1632$. This is arguably not a coincidence.

In Western culture [16], it is assumed that the most beautiful proportion between the sides of a rectangle is precisely $\Phi=(1+\sqrt{5}) / 2=1.618$ (the golden ratio), although this could be rapidly changing for Korea after the study of the Seokguram's rectangle relationship (Figures 17 and 18).

\subsection{Cosmic Implications with Buddhism}

As previously discussed, the inner drum of the temple is composed of reliefs that present twelve arahats, or disciples, that accompany the Buddha which have evolved eventually from the twelve animals of the Daoist credence but this time to the inside of the sanctuary. This fact reveals a clear tendency towards esoterism in Korean religion. Furthermore, the entrance is guarded by the four celestial Kings 四天王 (Shitenno, and they stand for wardens of the cardinal points), which have dedicated temples elsewhere in Korea and Japan. Other apotropaic figures such as Light and Darkness, Dragons and Giants, complete the awe-inspiring scene (Figure 19). 


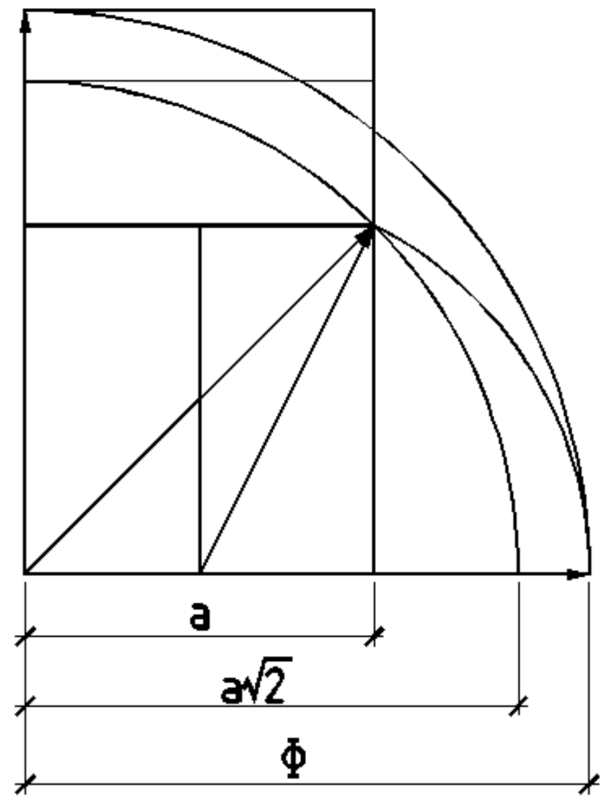

Figure 17. Difference between the Seokguram temple proportion and the golden ratio: one uses the diagonal of the square instead of the diagonal of a half square.

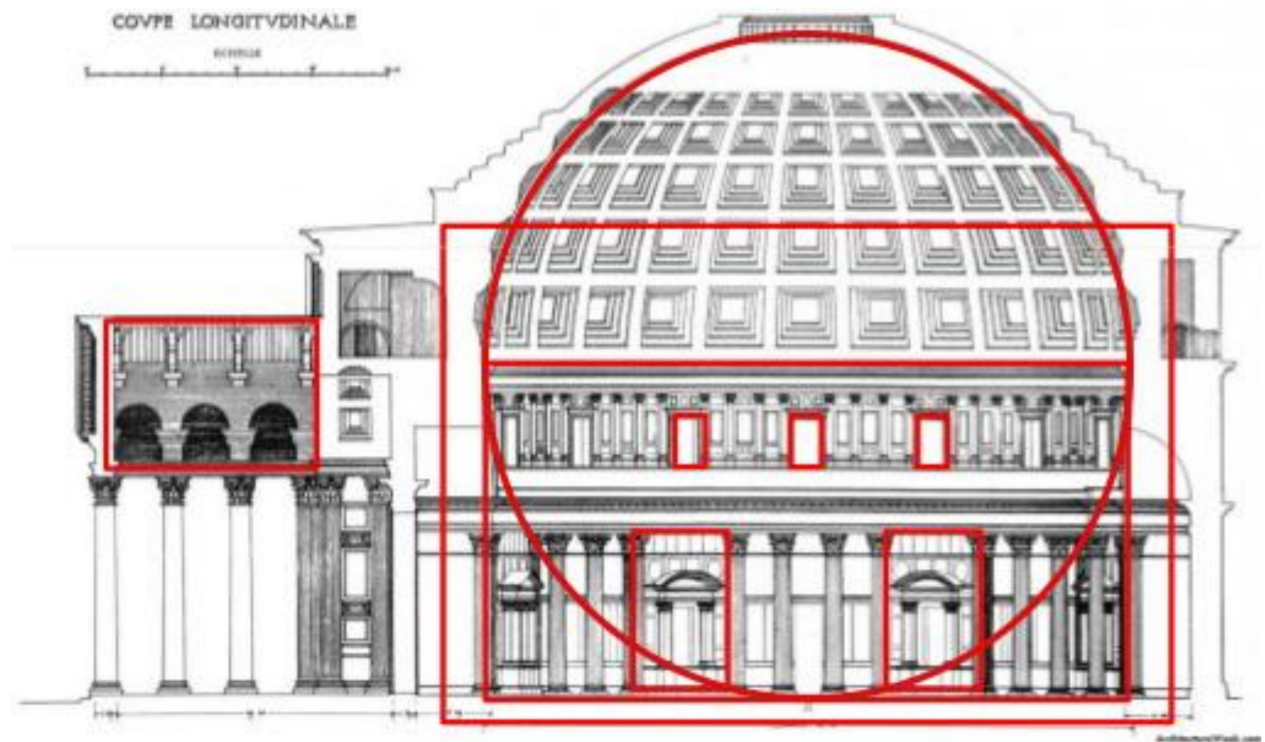

Figure 18. Roman Pantheon. Sectional golden rectangles.

The cosmic reconstruction of the Universe evoked in this reduced grotto further reinforces the philosophical ideas of the Buddhist order, such as the Garan 伽藍 (though originally meaning a monastery garden, it now represents the harmonic world of the Buddha) or Konpon Dait 根本大塔 $[17,18]$ (the main pagoda at the core of the garan which embodies the axis mundi). Both ideas were initially developed in Korea in the realm of Baechke and continued through the Silla period into the Heian period in Japan. The immaculate Buddha along with his entourage were intended to radiate and resonate through the universe and they still appear to do so if we judge them in the context of their diverse compositional schemes (Figures 16 and 20). 


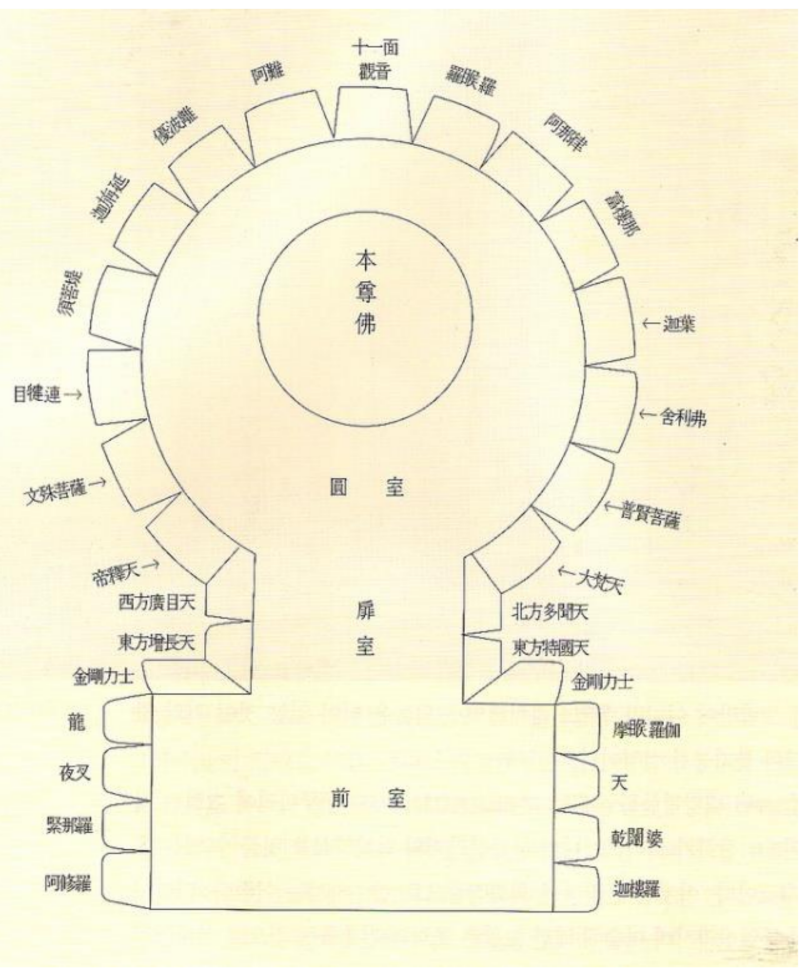

Figure 19. Plan of Seokguram indicating (in Chinese) the many different guardians and protective figures (four kings and arahats) that surround the Buddha in carved reliefs. Chinese names are given.

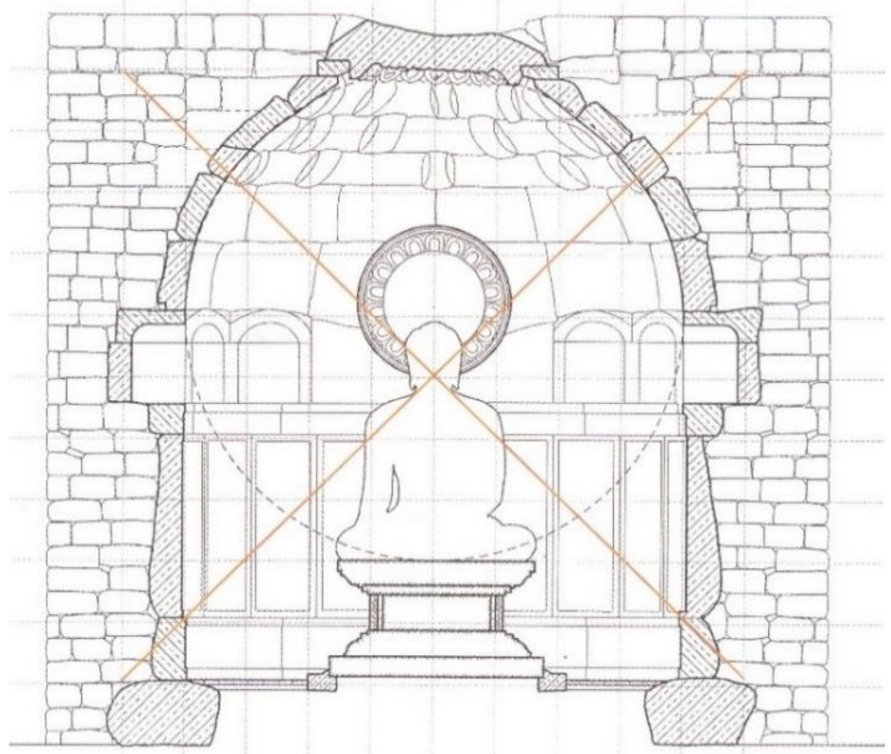

Figure 20. Vertical proportions of Seokguram showing the precise location in the center of the head of the Buddha.

A whitish granite statue, polished so as to resemble pure marble, in all likelihood inspired the pilgrims to contemplate how the stone turned into spiritual life. In this sense, Seokguram becomes one of these quintessential rarefied spaces, like Ryoanji or Ajanta, in which the combined effects of shimmering materials, subdued light and tenuous shades beckon and manifest the radiance of the supernatural (Figure 21). 


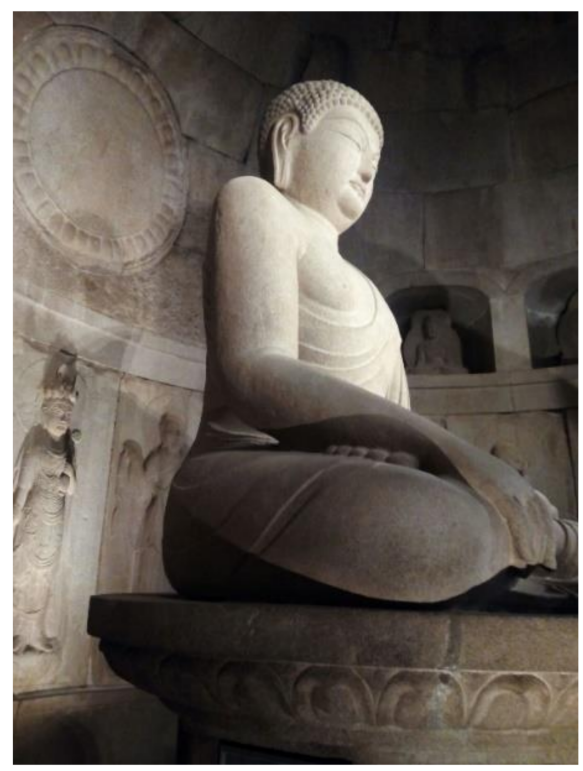

Figure 21. A view of inner tranquility at the central chamber of Seokguram.

\subsection{Structural and Luminous Behavior Analysis}

At this point in the study, the authors faced a key decision. We received precise information on the current interior dimensions of the grotto (obtained with high-tech equipment from the company Wipco (Seoul. Korea), 3D Scan and Solutions), that is to say, after the dismantling and subsequent piece-by-piece mounting of the temple during Japanese occupation, including later reforms during the 1960s and beyond. These data, although precise, lacked any kind of relationship with the supposed original plan of the project. In other words, they were incoherent data in which almost no element was perfectly circular or straight or spherical, and there was no available module to reconstruct the whole temple with such meagre figures.

We agreed to return to the assumed plan of the original architects of the temple and respect the trace found in Figure 16, with which a model can be constructed recalling the numbers 2, 6, 8, 10, 12, 17, 20 and 297.

We performed three approximations in order to address the problem. The first was to study the structural behavior of the dome without considering the 'forearms'. We then positioned the 'forearms' and compared the results in efforts and displacements. Finally, we analyzed a third hypothesis with 'forearms' and considered the existence of a hypothetical window in the front of the dome in order to determine if its presence compromised the structural security of the building [4].

Different views of the initial model are shown in Figures 22-28 corresponding to the common theories on the early proposals for the original shrine.

The results, although not totally conclusive due to some uncertainties about the nature of the materials used 1200 years ago, which are undoubtedly different to what we now possess and can be analyzed with modern techniques (see Appendix A), determine the extreme importance of the forearms to sustain the dome and keep it in place without damage, especially under the thrust of the overlying mountain and other unexpected forces that surely occurred over the course of the centuries [19]. At the same time, it has been proven that a reduced eastern aperture in the base of the dome would have been compatible with the overall stability of the construction. Thus, the authors have further investigated with their own specific software [20-22] the daylight distribution inside the grotto and additional effects as depicted in Figure 29. It is worth remarking that direct linkage of the statue and its chamber with the sun and the moon would have been demanded by the prevailing ritual cosmology of the epoch, as detailed in Sections 2.2 and 3.3. 


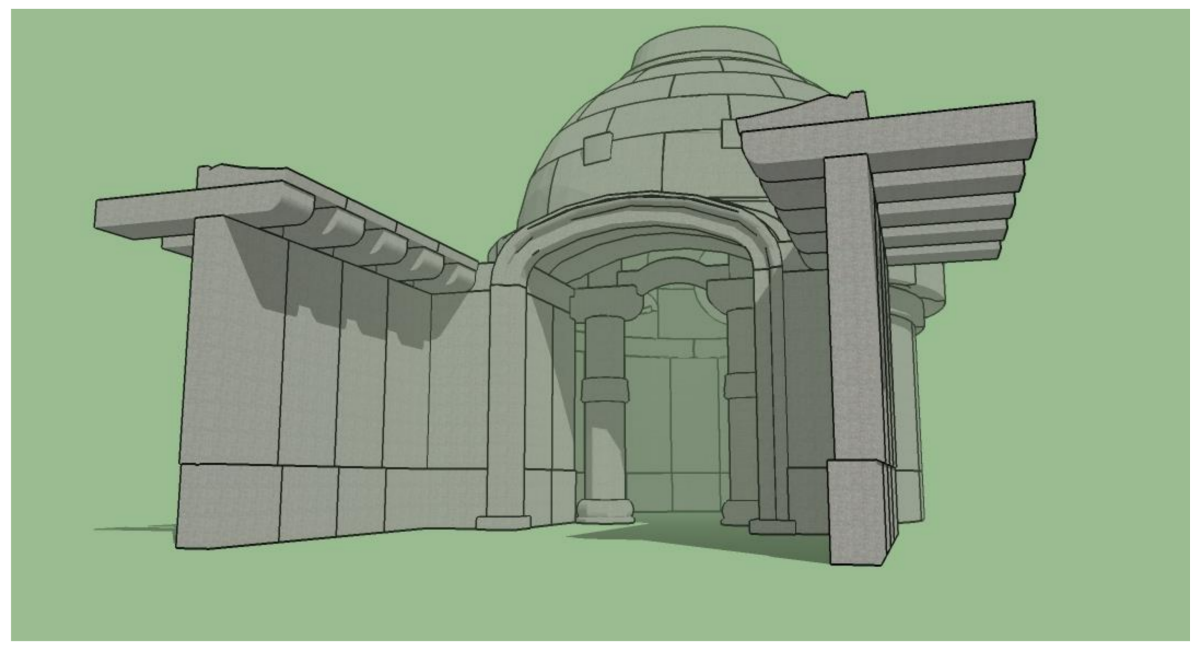

Figure 22. Model for the first structural study, assuming the absence of 'forearms'.

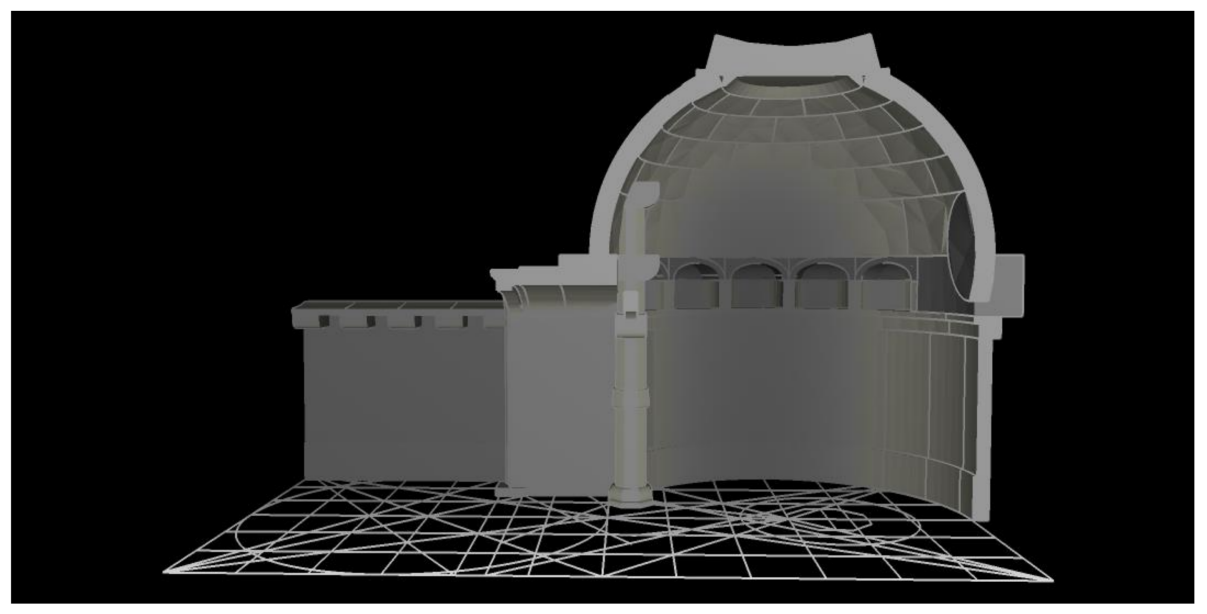

Figure 23. Section of the initial model.

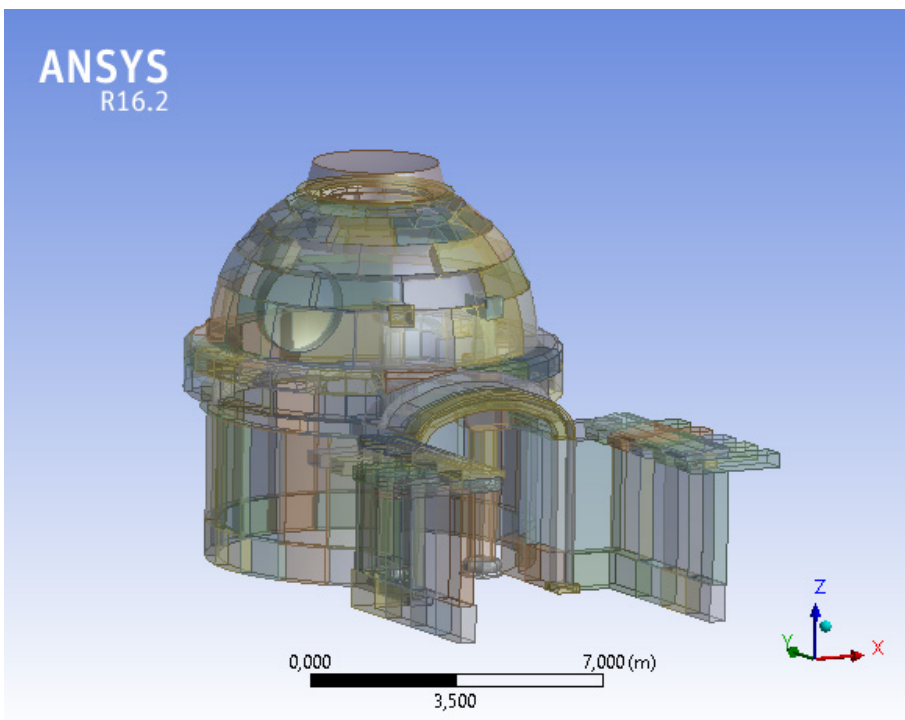

Figure 24. Process of importing the model to ANSYS. 


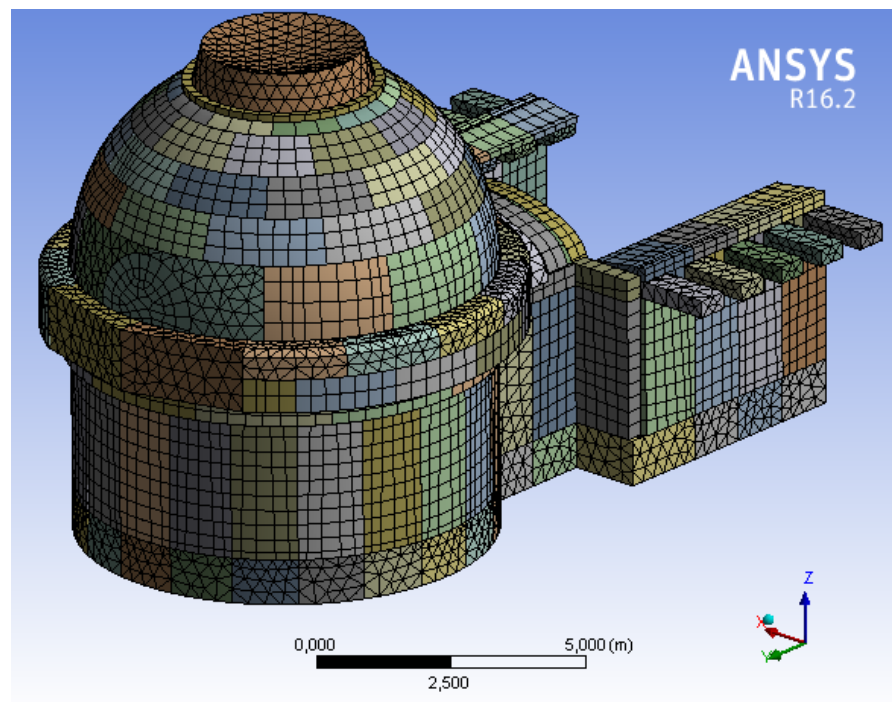

Figure 25. First test of meshing the structure.

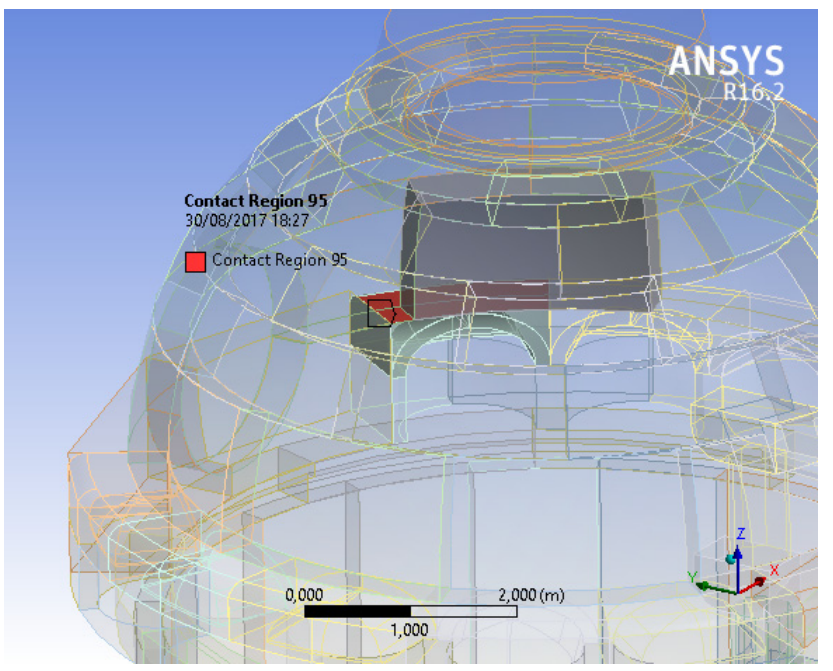

Figure 26. Rendering of one of the granite-granite contact regions. Coefficient of static friction $\mu_{e}=0.6$.

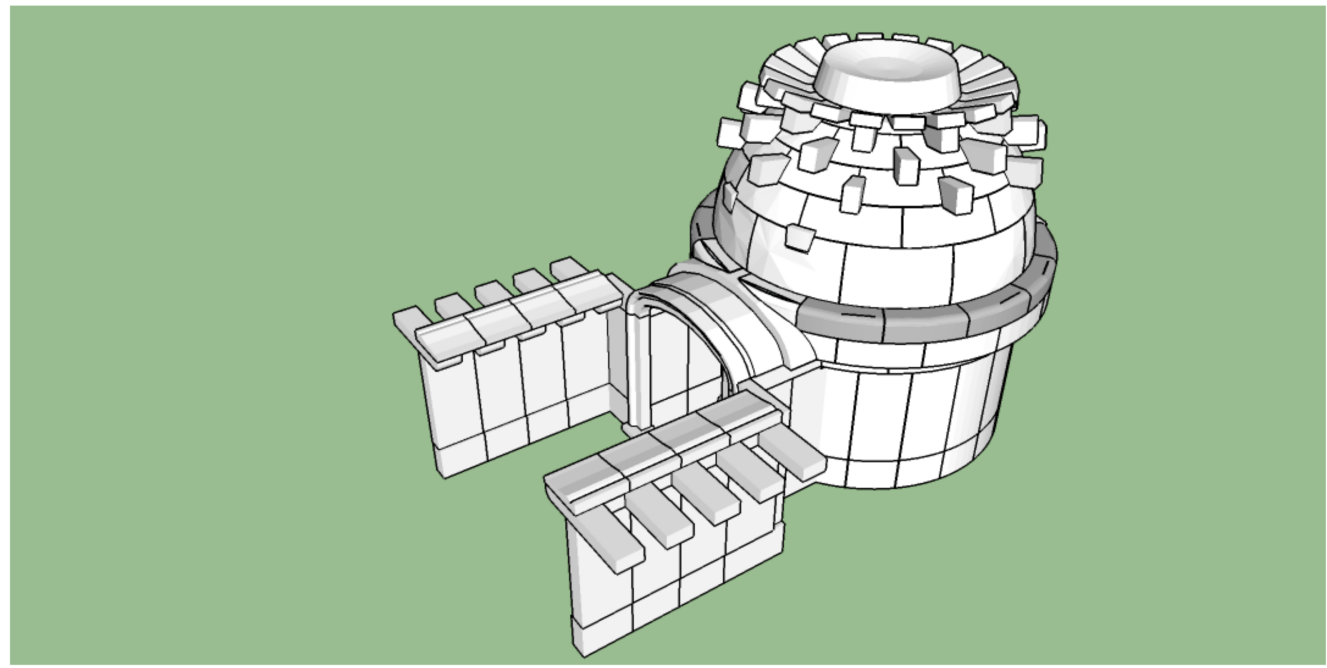

Figure 27. Visualization of the model in its current state. 


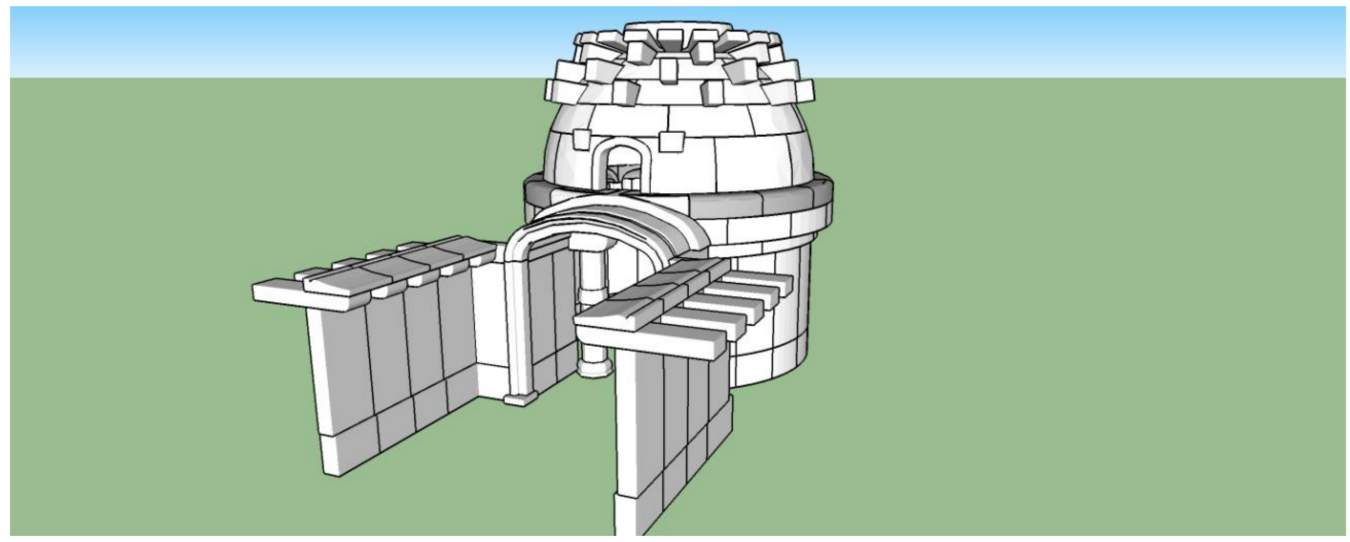

Figure 28. The model with a supposed opening in the front side to induce light effects.

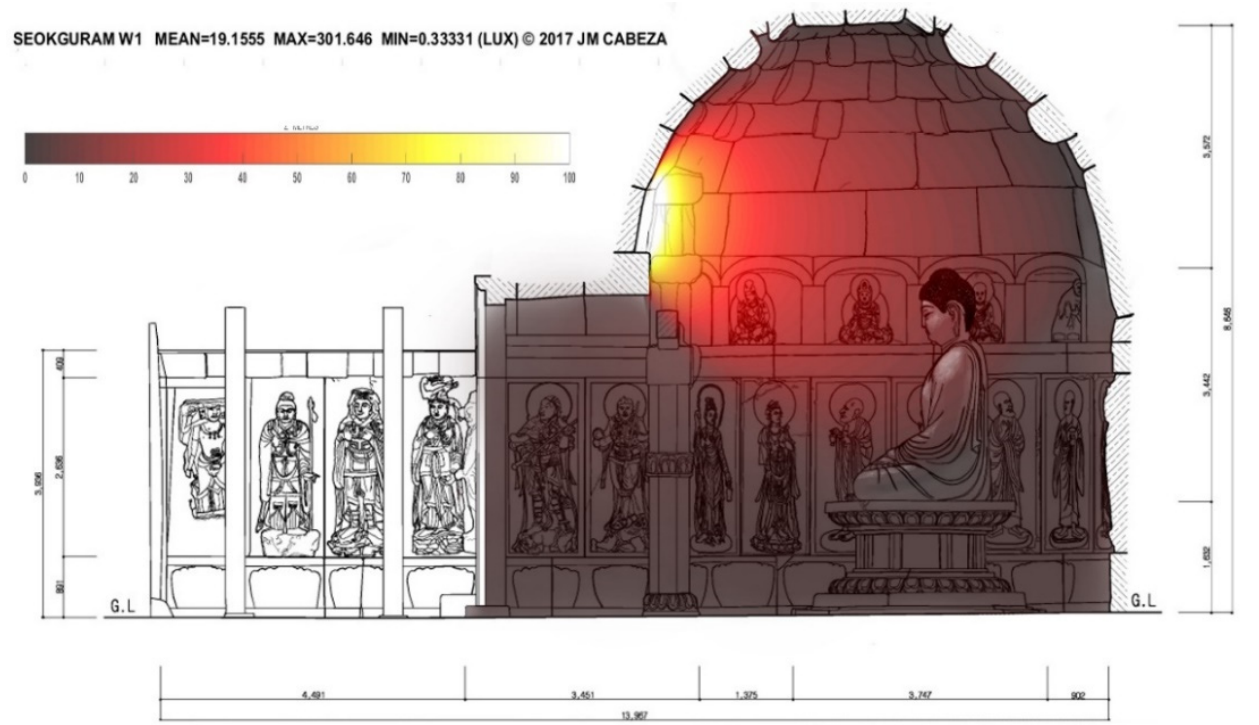

Figure 29. Sectional view of the grotto including simulation of lighting levels by a surmised circular opening oriented to the east.

\section{Discussion}

Founded on the previous results, the authors can demonstrate a tendency in heritage architecture, in which specific structures colligated to supernatural and cosmic harmony pertain to a well-rooted Asian tradition that should be increasingly recognizable in the years to come. In the authors' theory, such designs show a clear direction for the recreation of spaces of spirituality in Eastern Asia.

Two examples will suffice to settle the discussion and its limits. The first one is Tadao Ando's recent project for the renovation of a landscape cemetery on the outskirts of Sapporo (Japan).

To conceal an excessively imposing Buddha statue that the visitors apparently disfavored, Ando, inspired by the tradition of Buddhist grottoes like the Seokguram [5], executed an artificial earthen shell that generates an open dome shrine. The renovated complex is provided with ceremonial access and other facilities intended for religious services (Figures 30 and 31). The outer gentle slopes of the artificial mound are immersed in a mantle of lavender plants from which the hallowed head arises like "the sun on the waves of a purple sea" [5]. 


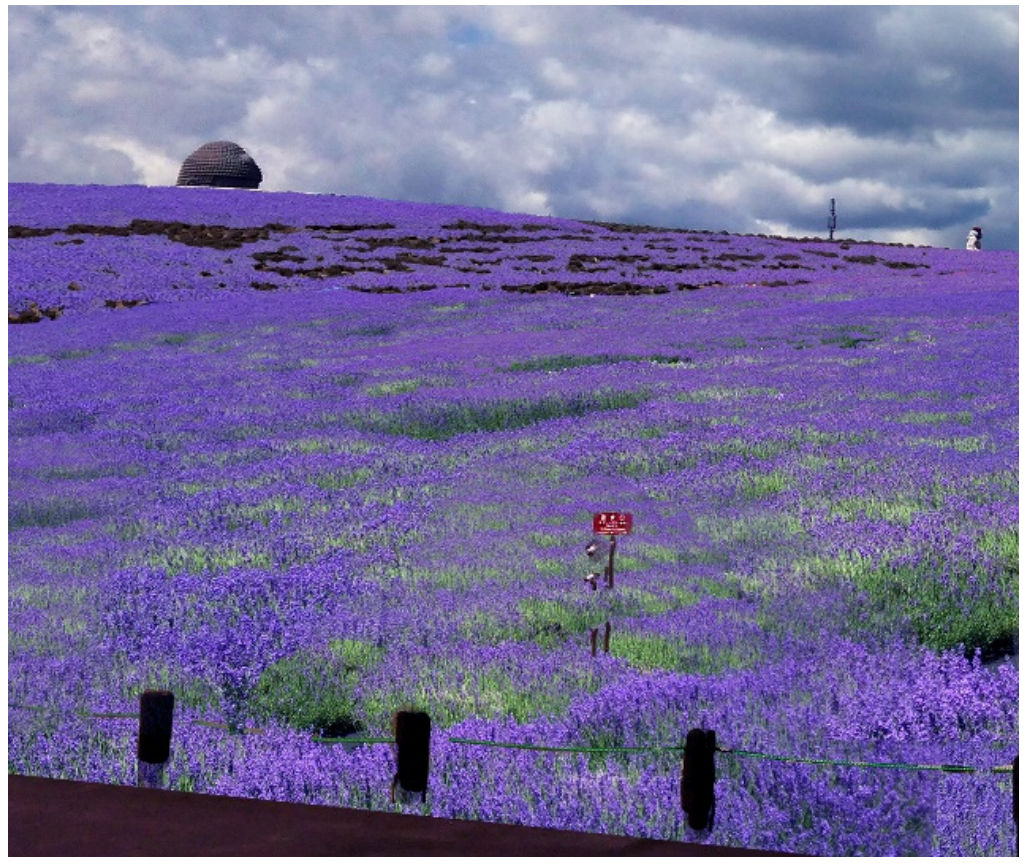

Figure 30. Tadao Ando, Hill of the Buddha (2017), with Buddha's Head emerging from a field of lavender shrubs, at Makomanai Takino Cemetery (Sapporo).

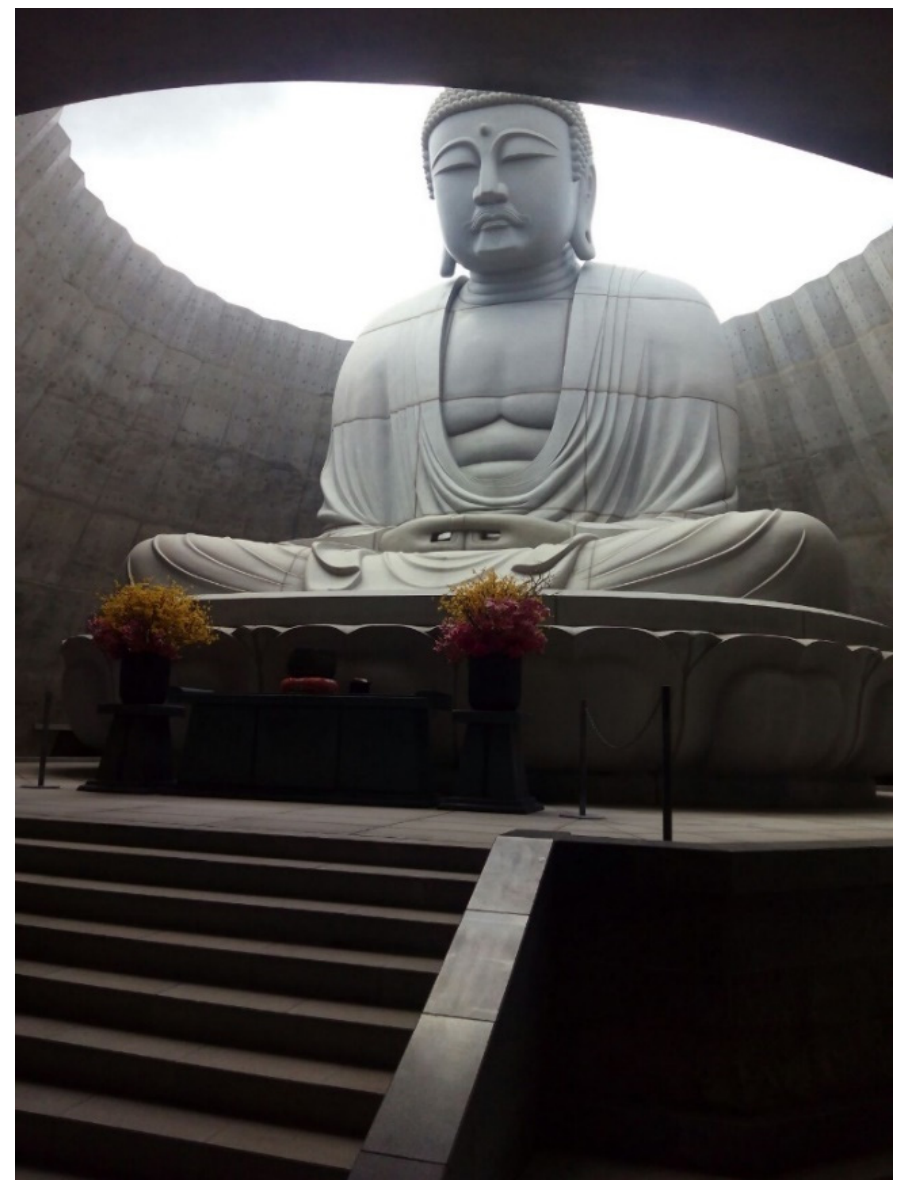

Figure 31. Tadao Ando's Buddha Hill at Makomanai Takino Cemetery (Sapporo). 
The structure has been acclaimed inside and outside Japan and it is said to be increasing the numbers of visitors to the Sapporo area interested in architectural heritage, even during the COVID-19 pandemic, and also visitors which seek its surmised healing powers.

The second case is introduced briefly by the authors. It consists in a proposal for a monument to the Holy Buddha at Gyeongju, the same city where the Seokguram is located [23].

It is worth mentioning that the authors were inspired by another ashlar construction from the oriental Roman outpost of Hierapolis (Turkey) (Figure 32). The semicircular apse is a typical feature of many ancient Roman buildings deriving from the primordial tumulus that we found in Etruscan precedents (Figure 8). We conceived that it was possible to complete the circle by means of conoid-like shapes, whose resistance and simplicity has been demonstrated in other articles [24-26].

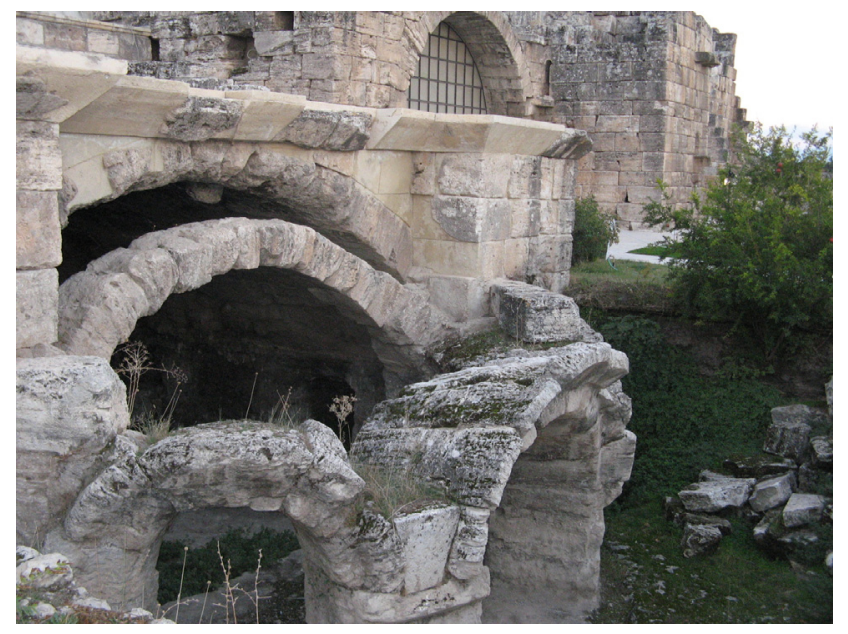

Figure 32. Three-lobed apse of stone at the Roman Baths in Hierapolis (Turkey).

The monument presents a curved frame organized by tiers in which every arch finds it support naturally on the keystone of the successive arches underneath (Figure 33). Our proposal develops in the symmetric shape of a lotus, which is the flower favored by Buddhism, as its leaves possess the property of rejecting water. It would be constructed mainly with stone and brick masonry and special reinforcements at the joints [27,28]. As scaffolding is not required for this type of structure, its erection would be relatively simple and so believers are intended to collaborate in this process. The concept of architecture as an ever-opening flower, exposed in the Lotus Sutra (saddharma pundarika sutra), is ta recognizable inspirational source for the authors' design. In this way, we hope to continue the endless legacy of Seokguram and protect its enduring heritage.

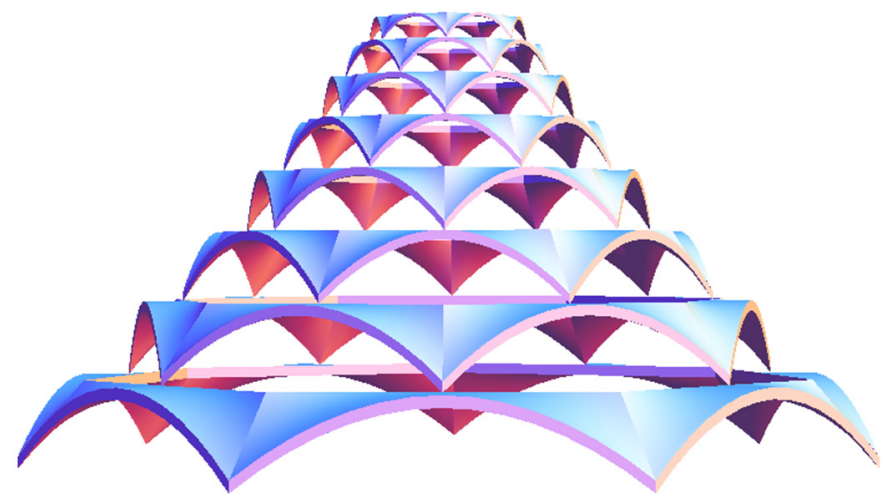

Figure 33. Proposal of an eight-tiered Buddhist monument. Elevation. 
An important limitation to the formerly suggested architectural developments is the necessity of organizing the space around contemporary religious statues of the Buddha. Presently, the tradition of sculpting such elements is dwindling in the modern societies of Japan and Korea, and specially in China, due to political controversies.

\section{Conclusions}

In these results and discussion we have brought to the surface how, in the 8th century A.D., the ancient builders of Korea possessed unforeseen knowledge of complicated techniques. In particular, the evolution from the ceremonial tumuli to the Buddhist chaitya must have been a strenuous process entailing decades of planning and craftsmanship. Such important heritage deserves to be protected and universally divulgated.

Based on this, the authors believe that there is an increasing demand in the architectural profession to disembroil the ancient and entangled forking threads in order to raise the true significance of our buildings.

We feel that it is imperative to ignite the signals that lead us into a future, not impassively but rather emotionally and humanely.

At the same time, thinking in retrospect, the authors have shown that the lessons learned from Seokguram and other derived enclaves are helpful when it comes to recognizing the path of creation towards a more serene architecture, which, in turn, brings a much desired link between buildings and nature or, in other words, sustainability. In moments of turmoil like the ones that the world faces today, architects and builders alike should carefully design spaces of hope and model of a common future where, sustained by unfailing compassion and humanity, we can fulfill our yearnings in the realm of architectural expression.

Author Contributions: Conceptualization, J.C.-L. and F.S.-A.; methodology, J.C.-L.; software, J.C.-L., F.P.-H. and F.S.-A.; formal analysis, I.R.-C.; investigation, J.C.-L. and I.R.-C.; writing-original draft preparation, J.C.-L. and F.S.-A.; writing—review and editing, J.C.-L.; visualization, I.R.-C.; supervision F.P.-H. All authors have read and agreed to the published version of the manuscript.

Funding: This research received no external funding.

Institutional Review Board Statement: Not applicable.

Informed Consent Statement: Not applicable.

Data Availability Statement: Not applicable.

Acknowledgments: F.S.-A. dedicates this article to his beloved son Francisco Salguero Jiménez. I.R.-C. wishes to recognize Maria Luisa Rodriguez Cunill and Antonio Maestre Cernadas. J. CabezaLainez feels indebted to Tomomi Odajima for offering sustain in endless travels and recognizes the indefatigable work and help of Lorenzo Muro. F.P.-H. wants to dedicate his work in this article to his master Alain Kermorvant, from the University of Tours, for the moments they shared in the islands of Malta. The endurance of Juhyung Lee is much appreciated by the authors.

Conflicts of Interest: The authors declare no conflict of interest.

\section{Appendix A. Fractional Hooke's Law, Continuum Damage Mechanics and the Weibull's Distribution for Granite's Behaviour}

In the ensuing section, we describe how we obtained a universal equation to model the stress-strain behavior of any material and apply it to granite. These values are necessary in order to introduce the parameters required by the software ANSYS to proceed with an analysis in accordance with the building under study.

\section{Appendix A.1. Fractional Hooke's Law}

Beginning with Cauchy's formula to calculate the iterated integral:

$$
{ }_{0} D_{x}^{-n} f(x)=\iint \ldots \int f(x) d x^{n}=\frac{1}{(n-1) !} \int_{0}^{x} f(t)(x-t)^{n} d t
$$


and from the generalization of the $\mathrm{n}$ ! notion introduced by Euler through the Gamma function:

$$
\Gamma(\mathrm{z})=\int_{0}^{\infty} \mathrm{t}^{\mathrm{z}-1} \mathrm{e}^{-\mathrm{t}} \mathrm{dt} \Rightarrow \Gamma(\mathrm{z})=(\mathrm{z}-1) !
$$

where $z$ represents any complex number with $\operatorname{Re}(z)>0$, Liouville [29] obtained the integral that bears his name, generalizing the natural number $n$ to any complex number with real part greater than zero, thus yielding the first formal expression for a fractional order integral—noninteger-:

$$
{ }_{0} D_{x}^{-\alpha} f(x)=\frac{1}{\Gamma(\alpha)} \int_{0}^{x} \frac{f(t) d t}{(x-t)^{1-\alpha}}
$$

This approach offers great possibilities of generalization with respect to the classical laws of Hooke and Newton about the behavior of materials. In fact, in 1947, Blair [30,31], highlighting that stress is proportional to the zero ordered derivative of strain in solids and also the first derivative in fluids, proposed intermediate materials, provided with quasi-properties, for which stress would be proportional to the intermediate ordered derivative-non-integer-of strain, that is:

Hooke:

$$
\sigma(t)=E \frac{d^{0} \varepsilon(t)}{d t^{0}}
$$

Blair:

$$
\sigma(\mathrm{t})=\mathrm{K}_{0} \mathrm{D}_{\mathrm{t}}^{\alpha} \varepsilon(\mathrm{t})
$$

Newton:

$$
\sigma(t)=\eta \frac{\mathrm{d} \varepsilon(\mathrm{t})}{\mathrm{dt}}
$$

where $\mathrm{K}$ and $\alpha$ would be dependent constants of the material $(0<\alpha<1)$.

Therefore, Hooke's law can be expressed as:

$$
\frac{\mathrm{d} \sigma}{\mathrm{d} \varepsilon}=\mathrm{E}
$$

In view of the approaches of the differintegral calculus, we can generalize the derivation order of this differential equation and propose a Hooke's law extended to non-integer derivation orders:

$$
{ }_{0} \mathrm{D}_{\varepsilon}^{\alpha} \sigma=\mathrm{K}
$$

Equation (A8) gives a fractional ordered differential equation of immediate solution:

$$
{ }_{0} \mathrm{D}_{\mathcal{\varepsilon}}^{-\alpha}{ }_{0} \mathrm{D}_{\varepsilon}^{\alpha} \sigma={ }_{0} \mathrm{D}_{\varepsilon}^{-\alpha} \mathrm{K} \Rightarrow \sigma={ }_{0} \mathrm{D}_{\varepsilon}^{-\alpha} \mathrm{K}
$$

which citing the definition of Liouville's fractional integral—Equation (A3)—results in:

$$
\sigma=\frac{1}{\Gamma(\alpha)} \int_{0}^{\varepsilon} \frac{\mathrm{Kdt}}{(\varepsilon-\mathrm{t})^{1-\alpha}}
$$

from which, integrating, we obtain,

$$
\sigma=\frac{\mathrm{K}}{\alpha \Gamma(\alpha)} \varepsilon^{\alpha}
$$

Therefore, we will use Equation (A11) in order to represent the behavior of the material points when the damage process, inherent in deformation, has not yet occurred.

\section{Appendix A.2. Continuum Damage Mechanics}

Originally proposed by Kachanov [32] and later modified by Rabotnov [33], the Continuum Damage Mechanics-CDM—has been widely accepted to simulate the complex constitutive behavior of many materials used in engineering. Specially, the models based on an internal variable of damage represented by a scalar function are characterized by their implementation simplicity and versatility. This variable of damage reflects the deterioration 
level of the material as it is strained and it turns real stresses into effective stresses, so a general equation that relates stresses with strains may be expressed as:

$$
\sigma=\Psi(\varepsilon)[1-\omega(\varepsilon)]
$$

where $\Psi(\varepsilon)$ represents the response of the undamaged material and $\omega(\varepsilon)$ is a scalar function of damage that ranges between 0 -when the material has not yet been stressed- and 1 -when such material collapses. The proposal we present in this study assumes that the function corresponds to the Weibull's probability distribution function.

\section{Appendix A.3. Weibull's Distribution}

The Weibull's theory of resistance of materials $[34,35]$ may be related to the hypotheses of Griffith [36] and Smekal [37]. In fact, assuming the existence of numerous weak zones within a material, either as microcracks-according to Griffith—or as dislocations in the atomic mesh-following Taylor [38-40]—or as Stone-Wales defects on Carbon NanoTubes (SWCNT) — according to Ebbensen and Takada [41] and Miyamoto et al. [42]—resistance would decrease from theoretical values. Assuming also that all those weak zones are of such a nature that they will break as soon as they reach a volume subjected to $\sigma$ stress and supposing that there are $\mathrm{n}$ weak zones per volume unit and that the $\sigma$ stress is concentrated within a small volume $\mathrm{dv}$, then the probability of breakage for the element of volume will be $\mathrm{dP}=\mathrm{ndv}$. If, instead of one, there are $\mathrm{N}$ elements of volume $\mathrm{dv}$ and the probability of breakage is $\mathrm{P}$, then the probability of survival will be $\mathrm{S}=1-\mathrm{P}=(1-\mathrm{dP}) \mathrm{N}=(1-\mathrm{ndv}) \mathrm{N}$, thus:

$$
\mathrm{P}=1-(\mathrm{ndv})^{\mathrm{N}}
$$

The total volume subjected to stress will then be $\mathrm{V}=\mathrm{Ndv}$ and we will receive:

$$
\mathrm{P}=1-\left(1-\frac{\mathrm{nV}}{\mathrm{N}}\right)^{\mathrm{N}}=1-\left(1-\frac{\mathrm{nV}}{\mathrm{N}}\right)^{\frac{\mathrm{N}}{\mathrm{nV}} \mathrm{nv}}
$$

However, if $\mathrm{N}$ increases as $\mathrm{dv}$ decreases indefinitely until $\mathrm{V}$ becomes constant, we obtain:

$$
\mathrm{P}=1-\lim _{\frac{N}{\mathrm{~N} V} \rightarrow \infty}\left(1-\frac{\mathrm{nV}}{\mathrm{N}}\right)^{\frac{\mathrm{N}}{\mathrm{nv} n v}}=1-\mathrm{e}^{-\mathrm{nV}}
$$

At this point, Weibull introduces his most famous proposal: if we choose $\mathrm{nV}=\int \omega(\varepsilon) \mathrm{dv}$ as

$$
\omega(\varepsilon)=\left(\frac{\varepsilon-\varepsilon_{\mathrm{a}}}{\varepsilon_{0}}\right)^{\mathrm{m}}
$$

then, as Weibull heralded, this function allows the data to be the ones that give us the distribution function $[43,44]$.

\section{References}

1. Choi, J.-S. Gyeongju, the Heart of Korean Culture: A UNESCO World Heritage; Hanul Publishing Group: Paju, Korea, 2011.

2. Yu, H.-J. Smiles of the Baby Buddha: Appreciating the Cultural Heritage of Kyǒngju; Changbi Publishers, Inc.: Paju-si, Korea, 1999.

3. Chatzichristodoulou, M.; Jefferies, J.; Zerihan, R. (Eds.) Interfaces of Performance; Ashgate Publishing, Ltd.: Farnham, UK, 2009.

4. Salguero-Andujar, F;; Cabeza-Lainez, J. Comparative, geometric and structural analysis of the Sǒkkuram Temple at Kyǒngju (Korea). In Proceedings of the Second National Symposium on Cultural Heritage of Korea, Gyeongju, Korea, 19-21 September 2017.

5. Cabeza Lainez, J.M. La Visión y La Voz: Arte, Ciudad y Cultura En Asia Oriental; UCOPress Ediciones Universidad de Córdoba: Córdoba, Spain, 2017.

6. Cabeza Lainez, J.M. Desde Sri Lanka hasta Japón: Ideas acerca de la evolución del Stupa. In La investigación sobre Asia Pacífico en España; Colección Española de Investigación sobre Asia Pacífico 1; San Ginés Aguilar, P., Ed.; Universidad de Granada: Granada, Spain, 2007; pp. 553-570.

7. Salguero Andujar, F.; Rodriguez-Cunill, I.; Cabeza-Lainez, J.M. The Problem of Lighting in Underground Domes, Vaults, and Tunnel-Like Structures of Antiquity; An Application to the Sustainability of Prominent Asian Heritage (India, Korea, China). Sustainability 2019, 11, 5865. [CrossRef]

8. Almodovar-Melendo, J.M.; Cabeza-Lainez, J.M. Environmental Features of Chinese Architectural Heritage: The Standardization of Form in the Pursuit of Equilibrium with Nature. Sustainability 2018, 10, 2443. [CrossRef] 
9. Rodriguez-Cunill, I.; Gutierrez-Villarrubia, M.; Salguero-Andujar, F.; Cabeza-Lainez, J. Sustainability in Early Modern China through the Evolution of the Jesuit Accommodation Method. Sustainability 2021, 13, 11729. [CrossRef]

10. Almodovar-Melendo, J.M.; Cabeza-Lainez, J.M.; Rodríguez-Cunill, I. Lighting Features in Historical Buildings: Scientific Analysis of the Church of Saint Louis of the Frenchmen in Seville. Sustainability 2018, 10, 3552. [CrossRef]

11. Cabeza-Lainez, J.M.; Almodóvar-Melendo, J.M. Daylight, Shape, and Cross-Cultural Influences Through the Routes of Discoveries: The Case of Baroque Temples. Space Cult. 2018, 21,340-357. [CrossRef]

12. Wertheim, M. The Pearly Gates of CyberSpace; W.W.Norton: New York, NY, USA, 2000.

13. Cabeza-Lainez, J.; Verdejo, J.R.; Macias, B.S.; Calero, J.I. The Key-role of Eladio Dieste, Spain and the Americas in the Evolution from Brickwork to Architectural Form. J. Asian Archit. Build. Eng. 2009, 8, 355-362. [CrossRef]

14. Ramswamy, S.G. Design and Construction of Concrete Shell Roofs; Krieger Publishing Company: Malabar, FL, USA, 2004.

15. Cabeza-Lainez, J.; López-de-Asiain-y-Martín, J.; Moreno-Jiménez, V. Rehabilitación del pabellón Plaza de América de la Exposición Universal de 1992. Revista de Edificación. Ecoconstrucción 1997, 26, 21-34. Available online: https://hdl.handle.net/10171/16978 (accessed on 10 December 2021).

16. Saraiva, L.; Martzloff, J.C.; Baldini, J.; Dhombres, J. História Das Ciências Matemáticas: Portugal e o Oriente-History of Mathematical Sciences: Portugal and East Asia; Fundação Oriente: Lisboa, Portugal, 2000.

17. Grayson, J.H. Korea: A Religious History; RoutledgeCurzon: London, UK, 2002; ISBN 0-7007-1605-X.

18. Kerr, A.; Sokol, A.K. Another Kyoto; Penguin Press: New York, NY, USA, 2018; ISBN-13: 978-0141988337.

19. Bunko, T. Memoirs of the Research Department of the Toyo Bunko (the Oriental Library); Publications-Toyō Bunko. Ser. B; The Toyo Bunko: Tokyo, Japan, 1926.

20. Salguero-Andújar, F.; Cabeza-Lainez, J.-M. New Computational Geometry Methods Applied to Solve Complex Problems of Radiative Transfer. Mathematics 2020, 8, 2176. [CrossRef]

21. Cabeza-Lainez, J.M.; Pulido-Arcas, J.A. New configuration factors for curved surfaces. J. Quant. Spectrosc. Radiat. Transf. 2013, 117, 71-80. [CrossRef]

22. Cabeza-Lainez, J.; Pulido-Arcas, J.A.; Sanchez-Montañés, B.; Rubio-Bellido, C. New configuration factor between a circle and a point-plane at random positions. Int. J. Heat Mass Transf. 2014, 69, 147-150. [CrossRef]

23. Cabeza-Lainez, J.M.; Xu, Y. Empire, Science and Geometry at the origins of early modern architecture. Symmetry Cult. Sci. 2020, 31, 321-351. [CrossRef]

24. Doganoff, I. Berechnung Von Kugelschalen Über Rechteckigem Grundriss: Mit Berechnungsdiagrammen; Mitteilungen aus dem Institut für Massivbau Hannover; Werner: Düsseldorf, Germany, 1962.

25. Doganoff, I.; Hoffmann, C.; Rühle, H. Shell and Fold Structure Roofs out of Precast, Pre-Stressed Reinforced Concrete Elements. 1964.

26. Cross, H. The Column Analogy; University of Illinois: Champaign, IL, USA, 1930.

27. Cabeza-Lainez, J. Las bóvedas de cerámica armada en la obra de Eladio Dieste. Análisis y posibilidades de adaptación a las condiciones constructivas españolas. In Tercer Congreso Nacional de Historia de la Construcción; Santiago, H., Ed.; CEHOPU: Madrid, Spain, 1996.

28. Cabeza-Lainez, J. Architectural characteristics of different configurations based on new geometric determinations for the conoid. Build. Spec. Issue: Archit. Integr. Art Eng. 2021, accepted for publication on 20 December 2021.

29. Liouville, J. Mémorie sur quelques question de géometrie et de mécanique et sur un noveau genre de calcul por resoudre ces questions. J. L'école Polytech. 1832, 13, 1-69.

30. Blair, G.W.S. Limitations of the Newtonian time scale in relation to non equilibrium rheological states and a theory of cuasiproperties. Proc. R. Soc. Lond. A 1947, 189, 69-87.

31. Blair, G.W.S. The role of psychophysics in rheology. J. Colloid Sci. 1947, 2, 21-32. [CrossRef]

32. Kachanov, L.M. On the time to rupture under creep conditions. Izv. Akad. Nauk SSSR Otd. Tekhn. Nauk 1958, 8, $26-31$.

33. Rabotnov, Y.N. A mechanism of a long time failure, in Creep Problems in Structural Members. USSR Acad. Sci. Publ. Mosc. 1959, 3, 112-117.

34. Weibull, W. A statistical theory of the strength of materials. Ing. Vetensk. Akad. 1939, 151, 1-45.

35. Weibull, W. A statistical distribution function of wide applicability. J. Appl. Mech. Trans. ASME 1951, 118, 293-297. [CrossRef]

36. Griffith, A.A. The phenomena of rupture and flow in solids. Phil. Trans. R. Soc. Lond. A 1921, 221, 163-198.

37. Smekal, A. Bruchtheorie sproder korper. Z. Phys. A-Hadron Nucl. 1936, 103, 495-525.

38. Taylor, G.I. The mechanism of plastic deformation of crystals. Part I. Theoretical. Proc. R. Soc. Lond. A 1934, 145, $362-387$.

39. Taylor, G.I. The mechanism of plastic deformation of crystals. Part II. Comparison with observation. Proc. R. Soc. Lond. A 1934, $145,388-404$.

40. Taylor, G.I. A theory of plasticity of crystals. Z. Krist. 1934, 89, 375-385. [CrossRef]

41. Ebbesen, T.W.; Takada, T. Topological and SP3 defect structures in nanotubes. Carbon 1995, 33, 973-978. [CrossRef]

42. Miyamoto, Y.; Rubio, A.; Berber, S.; Yoon, M.; Tomanek, D. Theoretical identification of Stone-Wales defects in nanotubes. Phys. Rev. B 2004, 69, 121413-121414. [CrossRef]

43. Salguero, F. On the Stress-Strain Curves for Concrete and Other Materials under Uniaxial Stress Testing. Ph.D. Thesis, University of Huelva, Huelva, Spain, 2012.

44. Salguero, F.; Romero, S.; Prat, F.; Arribas, R.; Moreno, F. Universal stress-strain equation for metallic materials. J. Mater. Civ. Eng. 2014, 26, 04014030. [CrossRef] 